7-15-2008

\title{
A Case for an International Investment Court
}

Gus Van Harten

Osgoode Hall Law School of York University, gvanharten@osgoode.yorku.ca

Follow this and additional works at: http://digitalcommons.osgoode.yorku.ca/all_papers

Part of the Law Commons

\section{Repository Citation}

Van Harten, Gus, "A Case for an International Investment Court" (2008). All Papers. Paper 259.

http://digitalcommons.osgoode.yorku.ca/all_papers/259

This Conference Paper is brought to you for free and open access by the Research Papers, Working Papers, Conference Papers at Osgoode Digital

Commons. It has been accepted for inclusion in All Papers by an authorized administrator of Osgoode Digital Commons. 


\title{
A CASE FOR AN INTERNATIONAL INVESTMENT COURT
}

\author{
Inaugural Conference of the Society for International Economic Law: \\ New Horizons of International Economic Law \\ Geneva, 16 July 2008 \\ Gus Van Harten \\ Assistant Professor, Osgoode Hall Law School, York University, Toronto \\ Comments welcome at gvanharten@,osgoode.yorku.ca
}

\begin{abstract}
The article elaborates on the lack of objective guarantees of independence and impartiality in the existing system of investment treaty arbitration. This founds a case for an international investment court to replace the existing system. The argument proceeds in three steps: (1) investment treaty arbitration is uniquely a form of public law adjudication, constituted at the international level; (2) as constituted it does not satisfy standards of independence and impartiality in public law adjudication; and (3) various reasons that might be offered to justify this failing are unsatisfactory in light of the importance of these standards. For this reason, states should be encouraged to establish an international investment court in accordance with well-known principles of judicial decision-making. Above all, alternatives to the existing system should be measured against the criteria that typically apply in public law, especially the related principles of openness and independence. Absent these criteria being met, one does not have a system that depoliticizes disputes and subjects them to the rule of law, or that warrants the utmost respect of all parties, above all developing states.
\end{abstract}


This article presents a case for an international investment court. It is a case and not 'the case' because the argument is presented relative to existing arrangements that use a treaty-based arbitration mechanism to resolve investment disputes between states and investors. The argument is also narrow in that it focuses on a central distinction between judges and arbitrators: the secure tenure of the former and the insecure tenure (case-by-case appointment) of the latter. This orientation of the argument leads by implication to the assertion that there is something wanting in terms of the independence and impartiality of arbitrators in the existing arrangements based on investment treaty arbitration. Given this, the present case is meant to respond to a critical flaw in an existing arrangement for international adjudication by elaborating upon an alternative.

It should be made clear from the outset that apparent bias in investment treaty arbitration is just that: it is a reasonable suspicion of bias (not actual bias) arising from structural failings of arbitration when used to determine matters of public law. The critique of investment treaty arbitration should thus not be taken as a condemnation of anyone involved in investment arbitration; there are many jurists, lawyers, academics, and business people of skill and integrity who sit as arbitrators and whose reputation is not sullied by an objective critique of the structure of the system and, in particular, its lack of objective guarantees of independence and impartiality. The difficulty is that the current structure of investment treaty arbitration casts a pall over all awards, and all legal interpretations, that emerge from the system in spite of the experience, qualifications, integrity, etc of the arbitrators, for reasons quite unique to this system and not to others where arbitration is used.

Ultimately it does not have to be this way. There are alternatives that are superior in their guarantees of impartiality and independence and that can be achieved without legal or intellectual acrobatics, with benefits for most if not all of the actors involved including states and their governments, including investors (except perhaps for those 
investors for whom litigation is a business strategy in itself), and including other systems that rely properly on arbitration to resolve disputes, especially commercial arbitration. The clearest alternative to the present arrangement is to establish an international investment court.

The broad outline of the argument presented here in favour of such a court is as follows. First, investment treaty arbitration is a form of public law adjudication in which the meaning of public law is resolved finally by adjudication. Second, for this reason, it should be evaluated according to standards that apply historically in public law. Third, the current system's failure to satisfy these standards, especially security of tenure, calls for an institutional arrangement that does satisfy them. Lastly, various counter-arguments that have been offered or that might be offered in opposition to an international investment court, founded on the principle of security of tenure in public law adjudication, do not warrant maintaining investment treaty arbitration as an alternative to such a court. For this reason, states should be encouraged to establish an international investment court in accordance with well-known principles of judicial decision-making in public law.

\section{A Underlying assumptions}

The case presented here borrows and elaborates on arguments presented elsewhere by the author ${ }^{1}$ and it remains grounded in the theoretical distinction between the use of arbitration to resolve regulatory disputes and its use to resolve commercial or other private disputes. There are powerful criticisms of public-private distinctions from various perspectives and the aim here is not to dismiss these, although in this paper the criticisms are not discussed in detail if at all. Rather, the aim here is to use the public-private distinction to elucidate specific differences in casting the major types of adjudication, while acknowledging the possibility that the distinction may

${ }^{1} \mathrm{G}$ Van Harten, Investment Treaty Arbitration and Public Law (Oxford University Press, 2007) ch 7 especially. 
leave gray areas or be simply inappropriate in some circumstances. Nevertheless, it is assumed that these limitations are not so pervasive or frequent in the present context as to defeat the underlying usefulness of the distinction.

The public-private distinction rests in turn on a concept of the state as sovereign. This concept too has received some negative press of late. The argument here is again quite pragmatic in its orientation. It refers to sovereignty as an instrument for identifying and analyzing certain activities of states as activities that states alone are able to engage in; for example, the passage of general rules accepted as binding in society and ultimately enforceable by the state's coercive power. Recognizing this uniqueness of the state as sovereign, arising from its role as the representative of a political group associated with a particular territory, is useful in that it helps to reveal the distinctiveness of the relationship between the state and those who are subjected to or affected by regulatory activity of the state. As a concept, sovereignty is a means of social ordering that is important (though of course not beyond challenge or doubt) and that has sufficient probative value here, it is suggested, to enable an elaboration of the sorts of disputes that arise between investors and states and how those disputes differ from disputes arising between parties that are equally capable of possessing legal rights and obligations.

In particular, an important aspect of disputes arising between a sovereign state and a foreign investor is that they are one-sided in that the entity on one side, the state, has a different set of powers and obligations in law than the entity on the other side, the investor. In some respects the state will possess rights that private parties cannot hold such that the state will have powers that are specifically sovereign. In other respects the state may be bound by sovereign obligations that a private party cannot possess or that a private party is in a unique position legally to avoid or abbreviate (by for example declaring bankruptcy). Where a dispute between a state and a private party occurs in relation to the state's exercise of these uniquely sovereign powers or its 
assumption of uniquely sovereign obligations, the dispute is described here as a 'regulatory dispute' and the adjudication of that dispute as a form of 'public law adjudication'.

Thus, for present purposes, the public-private distinction entails recognition of the state as an entity with unique characteristics and of this concept of the state as the basis for public law as a category of study, enabling (even if roughly or with doubt) a distinction between instances in which adjudication is used to resolve regulatory disputes and instance in which it is used to resolve disputes originating in a reciprocal relationship between juridical equals.

\section{B Argument}

1 Investment treaty arbitration as a form of public law adjudication

In applying this conceptual framework to investment treaty arbitration, the author has argued elsewhere (and will again only summarize that argument here) that investment treaty arbitration is a public law system, uniquely constituted at the international level, which replicates the structure of judicial review in domestic public law to a greater degree than other forms of international adjudication. In this respect, there is a key conceptual difference between investment treaty arbitration on the one hand and international commercial arbitration or conventional inter-state adjudication in public international law on the other. Both latter forms of international adjudication - international commercial arbitration and inter-state adjudication - are used to resolve disputes arising from a reciprocal legal relationship between the parties; that is, in international commercial arbitration, between private parties (one of which may be a state, acting in a private capacity) and in public international law between states (both acting in a sovereign capacity). In both contexts, either disputing party is equally capable of bringing a claim and of possessing legal rights and 
obligations; hence the underlying formal reciprocity. In the case of investment treaty arbitration, on the other hand, adjudication is used to resolve disputes arising between an individual and a state in relation to that state's assertion of its unique authority to regulate. The disputes arise in the context of a regulatory, rather than a reciprocal, legal relationship defined as such by the idea that the state in some cases exercises authority that no private party can possess.

For this reason, investment treaty arbitration is best analogized to judicial review in public law because it involves an adjudicative body having the competence to determine, in response to a claim by an individual, the legality of the use of sovereign authority, and to award a remedy for unlawful state conduct. Alternatively, it could be said that the adjudicative body issues a decision that has important consequences for the state, for the individual, and for others affected by what the decision means for the authority and conduct of the state, whether they are affected as taxpayers, employees, consumers, recipients of government programs, beneficiaries of regulation, and so on.

The public law character of investment treaty arbitration can be highlighted by looking at some of the questions that arbitrators have been called upon to answer in claims under investment treaties. For instance, they have determined whether a state violated a legal standard in an investment treaty by its national legislature enacting legislation that re-valued the state's official currency, by a judge of that state conducting a trial in a particular way, by its executive interpreting its tax laws or issuing a broadcasting license or determining an export quota. It is not necessary to examine the details of cases in which these questions arose or how they were resolved. The point is simply that, in terms of the legal questions at stake and the wider consequences for the community or society, these claims resemble the claims that are commonly resolved in the domestic sphere by way of constitutional or administrative law. That is, investment treaty arbitration is used to resolve regulatory 
disputes between those who govern and those who are governed. It is not used to resolve disputes arising from contractual or other reciprocal legal relations between private parties, one of which might very well be a state, but a state that is acting in a non-sovereign capacity.

The next step in the argument that investment treaty arbitration is a form of public law adjudication requires that it be distinguished from other instances where international adjudication is used to resolve claims involving the sovereign treatment of an individual by the state. Here, the uniqueness of investment treaty arbitration arises from its exceptional combination of five characteristics (which again are only summarized here). First, unlike in customary international law and the great majority of treaties, individuals are authorized to bring international claims against states in the context of the regulatory relationship, as opposed to a commercial relationship, with the respondent state.

Second, the state's consent to arbitration is prospective, unlike in the case of those international tribunals where individuals historically could bring claims, such as the Iran-US Claims Tribunal or historical claims tribunals formed after the Second World War (tribunals whose competence was limited either to existing disputes or to disputes arising from a particular historical event, such as a war or revolution).

Third, the primary remedy in investment treaty arbitration is a damages award against the state. As such, investment treaties establish a system of state liability in public law; indeed, they provide for damages awards against the state for acts of not only the domestic administration of the state but also its legislatures and its courts. The availability of this remedy distinguishes investment treaty arbitration from other forms of international adjudication that allow individual claims with the exception of a small number of international courts, including the European Court of Justice, the European Court of Human Rights, and with certain qualifications the Inter-American 
Court of Human Rights. In public law, the damages award for past unlawful conduct of the state is a very significant remedy because of its implications both for the budgets of states and for governmental decision-making writ large.

Fourth, unlike any other treaty, investment treaties often remove the duty of the individual to exhaust local remedies before an international claim can be brought. This is critical because it operates to eclipse the conventional role of the domestic legal system in mediating between the international and domestic spheres. Further, this removal of the duty to exhaust local remedies is entirely unique to investment treaty arbitration. It is perhaps the most important aspect of how investment treaty arbitration, unlike other forms of international adjudication, resembles so closely domestic public law.

Fifth, unlike other decisions or awards in public law, investment treaty awards are enforceable in the courts of as many as 160 countries with limited opportunity for judicial review, in particular for errors of law or unreasonable choices made by the arbitrators (ie, other than jurisdictional errors or serious procedural impropriety). As a result, the arbitrators are authorized to interpret important questions of public law without the possibility of review or correction by a court, whether domestic or international.

The combination of these elements distinguishes investment treaty arbitration from other forms of international adjudication. It is therefore accurate in my view to say that investment treaty arbitration is the closest the world has come to an international adjudicative body with compulsory jurisdiction over claims by individual against states in the regulatory sphere. That is, it is the closest we have come to an international constitutional or administrative court, if we understand such a body to be one that would allow individuals directly to initiate an adjudicative review of the 
regulatory conduct of the state, and to obtain a binding determination of the legality of state conduct as well as a powerful remedy.

But of course investment treaty arbitration is not a court at all. It is rather a system that relies on a private model of adjudication, arbitration, to resolve regulatory disputes arising from foreign ownership of assets.

2 Independence and impartiality in public law adjudication

The argument thus far has sought to identify investment treaty arbitration as a form of state-to-individual adjudication in the regulatory context and, in this respect, as something unlike international commercial arbitration or other forms of international adjudication in public international law. Accepting that investment treaty arbitration is a form of public law adjudication, it is appropriate to examine issues of independence and impartiality in the system against the relevant standards that apply in public law, and not in these other contexts of international adjudication. In doing so, one should begin with standards that normally apply to courts in public law. This is the focus of the second stage of the argument.

Normally, in public law, the adjudicative review of the state as the ultimate legislature and regulator on behalf of its people is reserved for a distinct branch of government called courts. Why a distinct branch? The primary reason historically was to separate the judicial function, involving the interpretation and application of the law in specific cases, from other branches of government. To achieve this separation it was thought necessary to ensure certain guarantees of independence for the judge, including by appointing the judge for set term; barring his or her removal from office other than for cause; guaranteeing the judge's salary; and ensuring certain guarantees of 
administrative independence involving the control by a court of its docket, the assignment of judges to cases, and so on. ${ }^{2}$

In the common law tradition, the security of tenure of judges is 'an original principle in the basic customary law of the constitution'.3 It has well-established roots dating from England's Act of Settlement 1701 which provided that judges could be removed no longer at the pleasure of the King, but only on the approval of both Houses of Parliament. ${ }^{4}$ This statute was an outcome of the Glorious Revolution, following the stands taken by Sir Edward Coke as Chief Justice to King James I and, in particular, his refusal to subject judicial decisions to overriding authority of the King (a stand for which he was dismissed by the King). The principle of security of tenure for judges of the realm, as enacted into law by the Act of Settlement, was in turn incorporated into the constitutions of the United States and other countries, including Canada, as a basis for separating the judicial function of the state from, especially, the executive function.

In the US context, Alexander Hamilton spoke in the Federalist Papers of the incorporation of security of tenure in the American Constitution in these terms: 5

As liberty can have nothing to fear from the judiciary alone, but would have everything to fear from its union with either of the other departments; ... [permanence in office] may therefore be regarded as an indispensable ingredient in its constitution, and, in great measure, as the citadel of the public justice and the public security.

Hamilton wrote further of the 'permanent tenure of judicial officers' that 'nothing will contribute so much as this to that independent spirit in the judges which must be

\footnotetext{
${ }^{2}$ NT Nemetz, 'Comment' in A Linden, ed, The Canadian Judiciary (Osgoode Hall Law School 1976) 16-17.

${ }^{3}$ WR Lederman, 'The Independence of the Judiciary' in A Linden, ed, The Canadian Judiciary (Osgoode Hall Law School 1976) 5.

${ }^{4}$ Lord Denning, 'The Independence of the Judges' (Presidential Address to the Holdsworth Club of the University of Birmingham, 1949-50) 7-8.

5 The Federalist Papers, no 78 (New American Library edn, 1961) 465-6.
} 
essentially to the faithful performance of so arduous a duty'. ${ }^{6}$ Here, permanency of tenure concerned chiefly judges' 'duration in office, the provisions for their support, the precautions for their responsibility.7

The origins of judicial security of tenure thus lie in the separation of judicial power from that of the executive. Regarding this, it is important in today's context not to limit oneself to domestic executive officials, but also to consider the prospect that international executives might likewise exercise power over international adjudicators in ways that call into question their independence and impartiality. Further, the power of private interests is also of concern, to the extent that such interests might also be in a position to wield inappropriate influence over the adjudicator or the adjudicative process in its determination of what the state is, what it is allowed to do in law, and what happens when the sovereign state is found to have done something unlawful. As Shimon Shetreet wrote in 1976:8

Independence of the judiciary has normally been thought of as freedom from interference by the executive or legislature in the exercise of the judicial function.... In modern times, with the steady growth of corporate giants, it is of utmost importance that the independence of the judiciary from business or corporate interests should also be secured. In short, independence of the judiciary implies not only that a judge be free from governmental and political pressure and political entanglement but also that he should be removed from financial and business entanglements likely to affect, or rather to seem to affect him in the exercise of his judicial function.

i Perceived versus actual bias

How do those principles of judicial decision-making apply to investment treaty arbitration? In the first place, it is important to clarify that our concern is not merely actual bias but also the perception of bias on the part of the individual adjudicator or

\footnotetext{
6 ibid, 469.

7 ibid, 465.

8 S Shetreet, Judges on Trial (Amsterdam: North-Holland Publishing, 1976) 17-18.
} 
adjudicative body. I draw attention to this only because it has been said that, without proof of actual bias or an actual conflict of interest on the part of an arbitrator, there is no problem with the current system of investment treaty arbitration. To insist on proof actual bias, however, entails a diminished standard of impartiality and independence, not only in the context of public law, but also in other contexts where arbitration is commonly utilized to resolve disputes. For all forms of adjudication, if we consider this a process by which a neutral authority that is not under the sway of one of the dispute parties, one speaks in terms of the absence of any 'apprehension' of bias, or any 'appearance' or 'suspicion' or 'danger' of bias, in order simply to make the point is that the concern for fairness and justice goes beyond actual bias and is measurable in terms of perceptions, based either on an objective standard or on subjective views of the parties themselves.

The Court of Appeal of England and Wales put it thus in the Locabail decision: ${ }^{9}$

.... objections and applications based on what, in the case law, is called 'actual bias' are very rare, partly (as we trust) because the existence of actual bias is very rare, but partly for other reasons also. The proof of actual bias is very difficult, because the law does not countenance the questioning of a judge about extraneous influences affecting his mind; and the policy of the common law is to protect litigants who can discharge the lesser burden of showing a real danger of bias without requiring them to show that such bias actually exists.

So there are good reasons for not limiting the evaluation to proof of actual bias on the part of an adjudicator. First, it would be unreasonable to hold a party to a requirement to prove actual bias given the difficulties in doing so. Second, it would be unbecoming of the adjudicative process to require the adjudicator to testify in advance as to his or her state of mind, opinions, etc. Instead, one speaks of the perception of bias. In Lord Hewart's famous formulation: 'it is not merely of some importance but is of fundamental importance that justice should not only be done,

${ }^{9}$ Locabail v Bayfield Properties [2000] QB 451, 471-2. 
but should manifestly and undoubtedly be seen to be done'. ${ }^{10}$ Or, according to the Supreme Court of Canada, it is required 'that the court or tribunal be reasonably perceived as independent': ${ }^{11}$

The reason for this additional requirement was that the guarantee of judicial independence has the goal not only of ensuring that justice is done in individual cases, but also of ensuring public confidence in the justice system....

Also according to the Supreme Court of Canada: ${ }^{12}$

Without that confidence the system cannot command the respect and acceptance that are essential to its effective operation. It is, therefore, important that a tribunal should be perceived as independent, as well as impartial, and that the test for independence should include that perception.

Now, in assessing whether there is a reasonable perception of independence, it is necessary to look for any indicators of possible bias or lack of independence that are specific to the individual adjudicator, whether judge or arbitrator. That is, is there a direct or indirect interest that raises a concern in light of the personal or professional connections of the individual adjudicator? Is there an attitudinal bias arising from what the adjudicator has written on matters relevant to the dispute before him or her? Has the adjudicator been involved in past in the dispute or the line of decisionmaking in question? Or has some conduct of the individual such as antagonism toward a party during a hearing raised a perception of a predisposition as to the result?

In the context of arbitration, these issues are often addressed in arbitrators' codes of conduct or in the rules of arbitration, and they inform the sorts of arguments that one sees arising in investment treaty arbitrations where a state has challenged the appointment of an arbitrator on the basis of an apparent conflict of interest. Such

10 The King v Sussex Justices ex parte McCarthy (1924) 1 KB 256, 259.

${ }_{11}$ Reference re Remuneration of Judges of the Provincial Court, [1997] 3 SCR 3, para 111-12.

${ }^{12} \mathrm{R} v$ Valente, [1985] 2 SCR 673, para 22. 
challenges have arisen from the role of the arbitrator as a counsel in other cases, from past advocacy of the arbitrator in matters related to the dispute at hand, from previous decisions of the arbitrator, and from statements made by the arbitrator at the hearing.

For example, Poland challenged the appointment of former ICJ justice Steven Schwebel in the Eureko arbitration based on (1) his working relationship with the firm Sidney Austin whose lawyers were advancing a separate investment treaty arbitration against Poland and (2) his own role as counsel (via links to same firm) for an investor in an investment treaty arbitration against another state, Argentina, in the Vivendi case and the fact that his arguments in that case relied in part on decisions made by the Eureko tribunal of which he was a member. Argument (1) was rejected by the Belgian Court of First Instance, whose decision was upheld by the Belgian Court of Appeal, in its application of provisions under the Belgian Judicial Code that allow for a challenge to an arbitrator's appointment when circumstance raise 'legitimate doubts' about his or her impartiality or independence. Argument (2) was also rejected by the Belgian Court of Appeal, although on the separate basis that the argument had not been raised by Poland before the Court of First Instance. The court also reportedly emphasized Mr. Schwebel's professional integrity as outweighing his sensibility and the goals he pursues as counsel or the possibility that his work as counsel and his working relationships with other counsel might influence inappropriately the decisions he makes as an arbitrator. ${ }^{13}$

Another example is Argentina's challenge in the British Gas arbitration to the appointment of Professor van den Berg on the basis of his past participation in other tribunals that had reached different interpretations of Argentina's arguments about

\footnotetext{
${ }^{13}$ C Verbruggen, 'Belgian Court Confirms Independence of Judge Schwebel' International Arbitration Newsletter (11 February 2008); D Vis-Dunbar and LE Peterson, 'Belgian Appeals Court rejects Poland's challenge to Arbitrator in Eureko case' Investment Treaty News (15 November 2007) www.investmenttreatynews.com.
} 
the meaning of the state of necessity under its bilateral investment treaty with the US and in customary international law. This challenge was referred to the International Chamber of Commerce's International Court of Arbitration, which rejected the challenge without providing reasons for its decision (as is the ICC's practice). This decision is reportedly subject to a further challenge by Argentina in the Argentine courts, based in part on the ICC not having given reasons for its decision. Further, in the National Grid arbitration, Argentina challenged the appointment of an arbitrator, Dr Andres Rigo Sureda, as president of the tribunal on the basis that his then law firm had appointed Dr Guido Tawil as an arbitrator in an arbitration between Duke Energy and Peru, and that Dr Tawil served concurrently as counsel in two other investment treaty cases against Argentina over which Dr Rigo Sureda had presided. Thus, the concern was that Dr Sureda would be sitting in judgment of a client of Dr Tawil, while Dr Tawil was sitting in judgment of a client of Dr Riga Sureda's law firm. This challenge was also rejected without reasons by the ICC International Court of Arbitration, which had been designated to hear the challenge by the appointing authority for the arbitration, the Permanent Court of Arbitration.

There have been other challenges to the appointment of arbitrators. With one exception, ${ }^{14}$ they have not succeeded to my knowledge (although some are still pending) and it is not suggested here that any of them should have succeeded in any particular case. The point here is simply that this is an area of inquiry, applicable to courts and to arbitration tribunals, that concerns matters of perceived bias; the common question is whether there is some characteristic of the individual adjudicator that raises concerns.

\footnotetext{
${ }_{14}$ Republic of Ghana v Telekom Malaysia Berbad (18 October 2004 and 5 November 2004, No HA/RK 2004.667 and HA/RK 2004.788) (DC The Hague) (concluding that a party-nominated arbitrator in an investment arbitration under the UNCITRAL Rules could not concurrently act as counsel to an unrelated party in an ICSID annulment proceeding that raised similar legal issues).
} 
This concern for an absence of any unacceptable perception - keeping in mind of course that the threshold for what is acceptable and what is not will vary in different adjudicative contexts - is thus common to most if not all forms of adjudication. On the other hand, what one does not see in arbitration, but what one should see where adjudication is used finally to determine public law, is the existence of the objective guarantees of independence that normally apply to courts. One of these guarantees is security of tenure, but as mentioned there are others relating to the remuneration of judges, their administrative independence, the openness of judicial proceedings, and so on. They are what the Supreme Court of Canada has referred to as: 'a set of "objective conditions or guarantees"... whose absence would lead to a finding that a tribunal or court was not independent. The existence of objective guarantees, of course, follows from the fact that independence is status oriented; the objective guarantees define that status. ${ }^{.15}$

These objective guarantees are absent, obviously, from arbitration where the arbitrator is appointed on a case by case basis. Arbitrators who are appointed on a case by case basis by definition do not have security of tenure. But is this really a concern? If one holds investment treaty arbitration to the established standards of judicial independence and impartiality in public law then the answer is yes, because the absence of security of tenure leads to a reasonable judgment that the system is stacked, to put it crudely, in favour of investors and against host states. Undoubtedly, in any adjudicative system, parties on both sides will sometimes claim that they lost unjustifiably and that they did not get a fair hearing. However, uniquely in the case of the present system because of its use of arbitration in public law, a perception of bias does operate structurally in favour of investors and against states and those on whose behalf states act.

\footnotetext{
${ }^{15}$ Reference re Remuneration, above n 11, para 112 (referencing Valente, above n 12, para 15 and 22).
} 
There are two elements to this. The first has to do with the designation under investment treaties of appointing authorities for arbitrators. Without security of tenure for the adjudicator, the entity that has the ultimate power to appoint in each case, after a claim has been filed, has much greater ability to influence the adjudicative process than if it only appointed the adjudicator once and for a set term. In a case by case system, the appointing authority has the power to choose the presiding arbitrator, in the absence of agreement between the state and individual, after examining in each instance the dispute at hand, the nationality of the claimant, the identify of the host state, and so on. Under investment treaties, this power is allocated to decision-makers that cannot be said to be reasonably free from bias in favour of foreign investors or, on the other hand, states. Rather, the institutions in question lean heavily toward the capital-exporting perspective and, by extension, toward foreign investors and the major capital-exporting states.

First, appointing authority is commonly exercised by the International Centre for the Settlement of Investment Disputes where appointing authority is exercised either by the Chair of the ICSID Administrative Council or by the ICSID Secretary General. The former is an ex officio position of the President of the World Bank who is in turn nominated by the US government and confirmed by the Bank's Board of Directors (where over 60\% of the voting power is exercised by Executive Directors from 11 major capital-exporting states); at present, this appointing authority is exercised by Robert Zoellick (formerly US Trade Representative); before that it was exercised by Paul Wolfowitz (formerly US Deputy Secretary of Defense, 2001-2005). Likewise, the ICSID Secretary General (customarily also the World Bank's Legal VP and General Counsel, although this customary practice is now reportedly slated to change ${ }^{16}$ ) is a person nominated by the Chair of the Administrative Council and approved by a two-thirds vote of the Administrative Council. In both cases, then, appointing

\footnotetext{
16 'After 40+ years, ICSID to have its own full-time Secretary General' Investment Arbitration Reporter (18 June 2008) www.iareporter.com.
} 
authority is vested in an official who is customarily chosen by the US Administration with the concurrence of other major capital-exporting states. As such, the system is somewhat comparable to earlier arrangements in investment contracts between US firms and Caribbean or Central American states, where disputes arising under the contract between the US investor and the host government were subject to resolution by arbitration, with default authority to appoint the presiding arbitrator resting with the US Secretary of State. ${ }^{17}$ At ICSID, the role of the US Administration is one or two steps removed from this quasi-colonial set-up in that the US Administration nominates the World Bank President - subject to appointment by a process in which 11 major capital-exporters hold a majority of the votes - who will then either exercise appointing authority or in turn select the ICSID Secretary General to do so. Given this structure, it seems reasonable for an informed observer to conclude that ICSID appointing authority will tend toward the position of the major capital-exporting states and their firms. Put differently, it is difficult to say that those who wield appointing authority at ICSID are free of a perception of bias in favour of investors, especially US investors. Indeed, some developing states have gone so far as to publicly challenged this proposition. ${ }^{18}$

Even so, this arrangement would be less problematic if ICSID appointed individual adjudicators for a set term of, say, seven years; if the appointments were nonrenewable; if the adjudicators were chosen for particular cases in a neutral way, such as by lottery; and if the appointments process took place as part of a public process involving a discussion of potential candidates by different groups of states and an opportunity for capital-exporting and capital-importing states both to influence the final decision. There would need to be more say given to the capital-exporting perspective than country-by-country or population-based voting would allow, if the

\footnotetext{
${ }^{17}$ RW Dunn, American Foreign Investments (New York: BW Huebsch and Viking Press, 1926) 357-8, 368.

${ }^{18}$ F Cabrera Diaz, 'Bolivia expounds on reasons for withdrawing from ICSID arbitration system' Investment Treaty News (27 May 2007); G Molina, 'Ecuador wary of World Bank arbitration in Occidental case' The Washington Post (11 May 2008).
} 
aim was to establish a system that had the confidence of investors. But it need not be a matter of control, as in the case of voting power among the World Bank's Executive Directors. At the very least, the guarantee of secure tenure would remove the ongoing discretion that ICSID officials exercise over states on a claim-by-claim, government-by-government basis.

Yet more troubling than the role of ICSID as appointing authority is the role under some investment treaties of business organizations that are accountable directly to investors and businesses. For example, some treaties (concluded mainly between European states and developing states) assign appointing authority to the International Chamber of Commerce (others assign it to the Stockholm Chamber of Commerce). Under the ICC Rules, arbitrators are appointed by the ICC's International Court of Arbitration, the members of which are nominated by the ICC world council of business on the recommendation of the ICC Executive Board. ${ }^{19}$ On its website, the ICC describes itself as 'the world business organization', as 'the voice of world business', and as an organization that 'speaks for world business whenever governments make decisions that crucially affect corporate strategies and the bottom line'. This conveys simply the point that the ICC is an association of businesses that represents the interests of its members, many of whom are foreign investors, and that can therefore be reasonably regarded as disposed more toward the business interests of investors than the regulatory priorities of states.

Indeed, it seems far-fetched to suggest that a business organization (or an adjudicative body the members of which are appointed by a business organization) can serve as a neutral appointing authority, where it has the authority to appoint arbitrators to resolve regulatory disputes between states and business. It is doubtful that such an arrangement would ever be accepted in a domestic context. Can one imagine a claim of 'unfair regulation', brought by a company, being submitted for

${ }^{19}$ Rules of Arbitration of the International Chamber of Commerce, revised 1 January 1998, art 1 and 9(3)) and app I (Statute of the International Court of Arbitration of the ICC, art 3). 
resolution by an ad hoc tribunal, the president of which was appointed by the local chamber of commerce? Not if one expected the claim to be resolved in a way that was regarded as credible by outsiders. Such an arrangement would appear rather as one meant to favour the business interest at the expense of genuine independence and impartiality.

The second element of this question of impartiality and independence - beyond the role of the appointing authority - is that security of tenure also insulates the adjudicator from influence by powerful private interests, so as to ensure that no one can say that the judge was predisposed to decide a case or interpreted the law in a way that would increase his or her prospects for future income and career advancement. Here it can be said (even where it is not the case) that arbitrators may be seen to interpret the treaties in ways that encourage claims by investors and, in turn, allows the relevant arbitration industry to thrive. That concern is unique to investment treaty arbitration, where the private model of arbitration is imported into the realm of public law, because only one class of parties (here the investor) activates the system by bringing a claim under the treaty.

WR Lederman wrote in 1976 that with the security of tenure of judges, "The conditions on which they hold office mean that they have no personal career interest to be served by the way they go in deciding cases that come before them. ${ }^{20}$ This removal of the career interest from the adjudicative equation is defeated when one assigns appointing authority on a case by case basis to executive officials; in the words of Lord Denning, without security of tenure, 'The judicial power is simply a part of the executive machine'. ${ }^{21}$ It is likewise defeated when security of tenure is removed in a one-way system in which only one class of disputing parties triggers use of the system.

\footnotetext{
${ }^{20}$ Lederman, above n 3, 11 .

${ }^{21}$ Denning, above n 4, 1.
} 
Thus, to retrace our steps, the underlying distinction between regulatory and reciprocal legal relationships is important because it suggests that public law disputes, and especially matters of law arising from such disputes, should not be left ultimately to arbitrators to resolve. Rather, they should be subject to the overarching authority of public courts, defined among other things by their presumptive openness and by objective guarantees of their independence and impartiality, in order to guard against the suspicion that the adjudicator has been swayed in their judgments by the power that others hold over his or her income and career. The argument is grounded in the importance of security of tenure to the evolution of an adjudicative system that can earn the utmost respect by all those whose rights or interests are engaged, above all those who are directly subject to its authority and who may be affected detrimentally by its outcomes.

\section{Reply to counter-arguments}

Certain counter-arguments have been advanced, and others may be anticipated, to this case for an international investment court. Most commonly in my experience it has been argued that there is no proof of actual bias in investment treaty arbitration and therefore no problem with the current system. Absent evidence or some case of actual bias, it is said, the requirements of independence and impartiality are satisfied. This counter-argument rests on a misconception not only of the standards of independence and impartiality that apply to judging in public law, but also of those that apply in other adjudicative contexts, including commercial arbitration. ${ }^{22}$ As discussed above, it is not usually a requirement in adjudication that actual bias be shown in order to disqualify an adjudicator from a particular case (although proof of

\footnotetext{
22 eg IBA Guidelines on Conflicts of Interest in International Arbitration (22 May 2004), explanation to General Standard 1 (referring to 'justifiable doubts' as to the arbitrator's 'ability to be impartial or independent').
} 
actual bias will of course suffice to disqualify). What is required is a showing of some reason for why the adjudicator may be reasonably perceived to lack independence and impartiality, even though he or she may well be capable of resolving the case in an independent way. Where one draws the line as to what perceptions constitute a sufficient reason to disqualify the adjudicator or adjudicative arrangement will vary according to the role and purpose of the adjudication. But only a very limited (and probably unfair) system of adjudication would insist on proof of actual bias as the sole check against impartiality and lack of independence.

Alternatively, it has been argued in response to this case for an international investment court that security of tenure is unimportant, 'artificial', or at least not central to ensuring impartiality and independence in public law adjudication. One who has great trust in the integrity of individual arbitrators may well hold this belief, and understandably. But not everyone is in a position to know enough about the integrity of the individual adjudicator in one case or another to be assured that his or her reputation is beyond doubt, especially when one learns of the business interest that inevitably arises where an adjudicator lacks secure tenure and can obtain appointment only case-by-case. This is why objective guarantees become so important. It should also be emphasized that those who dismiss security of tenure as a source of judicial independence are implicitly rejecting a long history of developed wisdom on the issue, and should be called on to elaborate clear arguments to explain why the inherited position is no longer thought important or relevant in investment treaty arbitration. No one has done so to my knowledge. The author prefers therefore to ride the coattails of Alexander Hamilton and company, and defend judicial security of tenure.

One might alternatively concede that standards of independence and impartiality normally present in public law are diluted in investment treaty arbitration, but that this is appropriate for some reason. For example, it might be said that the fact that 
investment disputes exist on the international plane makes it somehow inappropriate or unfeasible to import domestic ideals of judicial independence into that vaunted realm. States would never agree to it, one might lament, and investment treaty arbitration is the next-best alternative to the imperfections of domestic courts.

There are two problems with this counter-argument. The first is that states have regularly given tenure to international adjudicators in both state-state disputes ${ }^{23}$ and (however rare) individual-state disputes. ${ }^{24}$ They have also managed in many cases to appoint highly reputed individuals as jurists to the relevant adjudicative bodies. Why not encourage states to do the same in the present context of international investment disputes? Second, the argument falters perhaps in its preference for international arbitration over domestic courts if one accepts that the latter are in certain respects more capable than the former to deliver fair and legitimate decisions in the resolution of claims by foreign investors against host states. To adopt the presumption, as do many investment treaties by removing the duty to exhaust local remedies, that host state courts should be dismissed as simply incapable of delivering justice to foreign investors fails to account for claims brought against states like Canada and the United States, whose judiciaries have a status of constitutionalized independence that is much superior to that of international arbitrators. Further, it does not retain a space into which a state that successfully strengthens the capacity and independence (including by ensuring security of tenure and other objective guarantees) of its courts, as part of the state's democratic progress or transition, may position itself.

A more hopeful and in some cases more defensible option would be to adopt the presumption, as does customary international law, that local courts offer justice and

\footnotetext{
${ }^{23}$ eg International Court of Justice, International Tribunal for the Law of the Sea, Appellate Body of the World Trade Organization.

${ }^{24}$ eg European Court of Justice, European Court of Human Rights, Inter-American Court of Human Rights, International Criminal Court, International Criminal Tribunal for the Former Yugoslavia.
} 
to require the foreign investor to show otherwise as a precondition of an investment treaty claim (or perhaps to reverse the presumption by at least allowing the host state to defend itself against a treaty claim by establishing the independence of its courts). Where the duty to exhaust local remedies is removed, the preference for international arbitration operates not only as a mechanism to address failings of domestic courts but also as a means to privilege foreign investors by allowing them to evade judicial authority in public law, no matter how independent and capable of delivering justice the courts may be. Lastly, even if the duty to exhaust local remedies is removed, the more appropriate alternative to domestic courts - if one's aim is to limit political control over the resolution of investment disputes and subject them instead to the rule of law - is patently an international investment court, not a system based on case-by-case adjudicative appointment by executive or private business officials in a regulatory context that encourages arbitrators to adopt interpretations in favour of investors so as to encourage future claims.

Another counter-argument might be to point to administrative or quasi-judicial tribunals at the domestic level that are staffed by adjudicators who do not have secure tenure, but that resolve claims brought by individuals against the state in response to legislative or executive decisions. In domestic administrative law, it is sometimes said that judicial standards of independence must be moderated in order to facilitate the fair and expeditious adjudication of disputes about individual interests in the modern administrative state. That is, the state is simply so vast and complex that the machinery of government would seize up if all governmental decisions that affected an individual were subject to review by a fully independent court.

The author should confess that he is one who tends to emphasize the importance of maintaining conventional standards of judicial independence as much as possible, and of funding the courts accordingly, when dealing with even highly specific decisions of governments that affect an individual in a particularized way. Yet there is no need to 
invoke Dicey in order to distinguish the context of domestic tribunals in the modern administrative state from that of investment treaty arbitration. First, with the latter, one is not confronted with a flood of disputes that would overload the capacity of an international court. At present, the rate of claims brought under investment treaties is stable at a few dozen a year. It is not a case of the hundreds or thousands (or tens of thousands) of claims annually that domestic tribunals are often established to deal with. Also, states can surely afford the financial cost of an adjudicative body that satisfies judicial standards, or work creatively toward a funding mechanism that requires financial contributions by the disputing parties if that is thought prudent. Presumably, the priority is not to save several tens of millions of dollars a year, but to establish a system that is widely regarded as fair and independent, in the longer term interest of the system and those whom it seeks to protect.

Second, one is not dealing in investment treaty arbitration with the sorts of questions that are allocated to administrative tribunals in domestic law. The disputes at stake do not involve the removal of a liquor license or the disciplining of a lawyer or a doctor. Rather, they very often address the legality of legislative acts or broad policy decisions of government, leading to the potential re-allocation of substantial public funds to private business. These questions are of a different order of significance from those usually resolved by domestic tribunals. It is also noteworthy that domestic tribunals, even when they handle large numbers of claims, are often staffed by members who have a set tenure and who are not assigned on a case-by-case basis at the pleasure of the executive. As such, the standard of independence and impartiality that is offered by many domestic tribunals, although they deal with less weighty matters, surpasses that of investment treaty tribunals.

Third, and most importantly, where a decision of a domestic tribunal does engage important questions of general law, the decision can be appealed to an independent court. This is not the case in investment treaty arbitration, where questions of law 
decided by arbitrators are not subject to review in a court, whether domestic or international, to assure their correctness or reasonableness.

There are of course other possible counter-arguments. One might argue that, if adjudicators under investment treaties were required to commit to a lengthy term of service, states would not be able to attract those with the desired experience or expertise. This is not a flippant objection and one should not underestimate the challenge of identifying the best possible candidates for such an important role as membership on an international investment court. However, considering the willingness of many prominent judges, practitioners, academics, and officials to accept appointments as arbitrators in the present system, it seems doubtful that one would face a shortage of highly qualified persons who were willing to serve, even if it required them to relinquish income or career opportunities elsewhere. Some would no doubt decline the opportunity for very understandable reasons, but there would likely be others to take their place, and they should at least be invited to step forward. Finally, the system might benefit from widening the pool of recruitment by drawing on persons with experience and expertise in fields of law and policy beyond those of international investment or commerce, in light of the breadth of issues that may be generated by regulatory disputes between business and state.

Another counter-argument might be that the parties should be permitted to choose an adjudicator or adjudicative process that they believe will better serve to deal with disputes between them. That is a compelling argument in many contexts where arbitration is used, as in commercial arbitration, labour arbitration, and perhaps family arbitration. But in the case of investment treaty arbitration it runs into the first stage of the case presented here. Regulatory disputes between states and investors are not disputes between juridical equals. They are a matter of public law, where the fictional behemoth of the sovereign state has myriad relations with all private parties within its jurisdiction and affected by its governing choices, and where it is up to the 
institutions of the state to decide on the forms of decision-making and adjudication that will be made accessible to individuals who wish to challenge the sovereign. In this context, it is more accurate to say that the state (or states, by treaty) authorized a particular form of dispute settlement that the individual subsequently opts to take advantage of, as where a person brings a claim against the state under a domestic statute or constitution. To reduce such arrangements for public law adjudication to the conceptual framework of a consensual agreement between disputing parties given the singular and over-arching role of the state's decision to establish the arrangements as a means to govern the state's regulatory authority - is artificial.

Along the same lines, it was recently put to the author, following a conference presentation, that ICSID plays a limited role as an appointing authority because it appoints the presiding arbitrator in just 3\% of cases. I confess to not knowing the frequency of actual appointments as a proportion of potential appointments by ICSID. It is firstly not a straightforward figure to calculate. Does one measure ICSID appointments as a proportion of all presiding arbitrators who take part in arbitrations that are subject to ICSID appointing authority, for example? Or does one measure ICSID appointments as a proportion of all appointments in such arbitrations, including appointments of the party-appointed arbitrators? A further complication is that awards do not always indicate in the text whether the presiding arbitrator was appointed by ICSID in the exercise of its compulsory power, or by some other means.

However, the author tested the figure of $3 \%$ in a preliminary way by reviewing investment treaty awards, decided before 1 September 2006, on which the relevant data was at hand (ie a statement in the award indicating who appointed the presiding arbitrator). This yielded these results. Of 26 cases reviewed, ${ }^{25} 16$ were pursuant to the

\footnotetext{
${ }^{25}$ Cases pursuant to ICSID Rules: LESI v Algeria (co-arbitrators appointed president); Lanco v Argentina (SG ICSID appointed president with agreement of parties); Aguas del Aconguija \& Vivendi v Argentina (Chair of AC appointed president); Enron v Argentina (Chair of AC appointed president);
} 
ICSID Rules, and ICSID appointed the presiding arbitrator in $69 \%$ of those cases. The other 10 cases were pursuant to the UNCITRAL Rules, and the designated appointing authority (ICSID in 9 of the 10 cases; Stockholm Chamber of Commerce in the remaining case) appointed the presiding arbitrator in $40 \%$ of those cases. Thus, even adopting assumptions that understate the role of the appointing authority - by excluding annulment committees (as did the author in gathering the 26 cases), by including party-appointed arbitrators in the calculation, and by assuming that all party-appointed arbitrators were in fact appointed by the relevant party although in fact they were in a few cases appointed by the appointing authority - then the result is that ICSID appointed 23\% of total arbitrators in ICSID cases, and the designated appointing authority appointed 19\% in ICSID and UNCITRAL cases combined. On these assumptions and preliminary findings, the figure of $3 \%$ appears a significant underestimate.

Regardless of the frequency of ICSID appointments, a more important point is that the power of an organization to appoint arbitrators goes beyond the actual exercise of that appointing authority. Negotiations between the disputing parties about who they should agree to appoint as president of a tribunal are shaped by their estimation of how the designated authority will exercise its power to appoint if called upon to do so. The appointing authority also normally has the power to resolve claims that a

CMS $v$ Argentina (Chair of AC appointed president); LG\&E v Argentina (SG ICSID appointed president with agreement of parties); Siemens $v$ Argentina (Acting SG ICSID appointed president); Sempra $v$ Argentina (Acting SG ICSID appointed president); AES $v$ Argentina (SG ICSID appointed president); Continental Casualty v Argentina (Chair of AC appointed president); Gas Natural v Argentina (Chair of AC appointed president); Plama v Bulgaria (Chair of AC appointed president); Goetz $v$ Burundi (Chair of AC appointed president); Casado v Chile (Chair of AC appointed president); MTD Equity $v$ Chile (by agreement); Champion Trading v Egypt (SG ICSID appointed president with agreement of parties). Cases pursuant to the UNCITRAL Rules: Ethyl $v$ Canada (ICSID appointed president); Pope \& Talbot v Canada (SG ICSID appointed president); SD Myers v Canada (by agreement); Lauder v Czech Republic (by agreement); Saluka v Czech Republic (by agreement of coarbitrators); Swembalt v Latvia (by agreement of co-arbitrators, one party-appointed arbitrator appointed by SCC Institute on nomination as appointing authority by SG PCA); International Thunderbird v Mexico (SG ICSID appointed president); Link Trading v Moldova (SCC Institute appointed president and one party-appointed arbitrator on nomination as appointing authority by SG PCA); Canfor v US (initial panel by agreement); Consolidated Softwood Lumber v US (SG ICSID appointed all three members). 
particular arbitrator has a conflict of interest or is otherwise impartial, and ICSID itself appoints all three members of ICSID annulment committees.

It is thus not convincing to argue that investment treaty arbitrators do not require security of tenure because the disputing parties often reach agreement on who should be appointed as presiding arbitrator. Such agreements are reached against the backdrop of the parties' perceptions of the probable predilections of those who the appointing authority would otherwise likely appoint. Indeed, if the role of the appointing authority was inconsequential, why is such care taken by the major states to ensure that their treaties assign appointing authority to organizations whose voting power is dominated by capital-exporting states or by international business? Lastly, it is indicative of the broader argument that a similar apprehension of perceived bias has been expressed by representatives of Western firms concerned about the role of the China International Economic and Trade Arbitration Commission as appointing authority in contract-based arbitrations between foreign firms and state-owned companies in China. ${ }^{26}$

A final argument might be to plead a fait d'accompli by arguing that states have made the choice to use arbitration in this manner, and that is it. This is a profoundly powerful case where the objective is to interpret and apply the law as it stands. There may be constitutional limits to the delegation of judicial power to private arbitrators in some states, and the fact that states have resorted to arbitration to resolve public law may have implications for the system more broadly, perhaps in terms of the recognition and enforcement of awards. But there can be little, if any, doubt that the states parties to investment treaties intended to allow arbitrators who do not have secure tenure to resolve the relevant disputes. Nevertheless, this does nothing to undermine the argument presented here given that its object is to explain why states should not have made, and should not continue to make, this choice. The existing

26 A Batson, 'Concerns about China arbitration rise' W all Street Journal (9 May 2008). 
arrangement does not satisfy standards of judicial impartiality and independence; this inadequacy can be addressed by establishing an adjudicative body that satisfies those standards. It is quite clear at this stage what states did; the point is they got it wrong.

Some of these counter-arguments (and there are no doubt others not canvassed here) are more compelling than others, but none warrants abandonment of the case for an international investment court. None explains in particular why it is preferable to use arbitration to resolve investment disputes rather than to ensure the utmost integrity of adjudicative decision-making in the regulatory domain by incorporating objective guarantees for judicial independence and impartiality.

\section{Conclusion}

The skeletal argument presented here is (1) that investment treaty arbitration is a form of public law adjudication, (2) that it fails to satisfy standards of independence and impartiality in public law, and (3) that various reasons that might be offered to justify this are unsatisfactory in light of the importance of these standards. The next step is to ask: what sort of international investment court is required and how best should one seek to establish it? There are many possibilities and opportunities. An international investment court could be multilateral, regional, or bilateral. It could be a full court or an appellate body court that would hear appeals from decisions made in the first instance by arbitrators. It could be an autonomous entity or housed within existing institutions. It could be staffed by dedicated judges or via a roster of jurists who sit on domestic courts. Ultimately, it is not so important to arrive at a specific design for an international investment court that suits all states or all commentators. Much more important is to recognize that the present system is flawed and call upon states to address this flaw. Ideally, states will act jointly to do so but to the extent that cooperation proves elusive, like-minded states should not hesitate to pursue alternatives to investment treaty arbitration with respect to their own treaty networks. 
The critical point is that alternatives should be measured against the criteria of judging in public law, especially the related concepts of openness and independence. Without these standards being met, one does not have a system that depoliticizes disputes and subjects them to the rule of law, or that deserves the respect of all interested parties, above all developing states. At present, when Argentina or Ecuador or the Czech Republic is unsuccessful in an investment treaty arbitration, its government and people have justifiable reason to reject the result as unfair, the process as structured unfairly against the host state, and the award as inferior in legitimacy to that of a court decision.

There is clearly an important role for arbitration in contexts outside of public law, where the concerns elaborated here are much less pertinent. There is also a need for international adjudication to address concerns arising from domestic regulation of foreign investment in a global economy and the threat of arbitrary or discriminatory treatment by host governments. In this respect, it would be beneficial for investors in general, as well as states, to establish a system that is widely regarded to be free of perceived bias. And regardless of one's views about whether there is a sufficient basis for doubts about the integrity of decisions emanating from the current system, why risk the possibility of many believing this to be the case? There is a clear alternative that is achievable, with awareness and political will, and states should be encouraged to pursue it.

Lastly it is important to reiterate that the argument here is not an indictment of individual arbitrators. It is more an indictment of those public decision-makers who have chosen to rely on arbitration in matters of public law. Many arbitrators are justifiably admired for their integrity. But it is not enough to rely on the personal reputation of arbitrators when adjudicating public law. As Lord Prosser explained in a 
decision of the English High Court ${ }^{27}$ that dealt with the appointment of temporary sheriffs in Scotland by ministerial officials and whether this met the guarantee in the European Convention on Human Rights of the right to a fair hearing before an 'independent and impartial tribunal established by law':

I am not suggesting in any way that there has ever been any impropriety, either on the part of temporary sheriffs or on the part of any holder of any ministerial office, or of their officials. But I would add that if a judge is not independent, then however great his integrity, it may be very difficult for him to know whether his want of independence affects the way in which he carries out his judicial duties. And however determined a minister or public servant may be to carry out his functions in relation to the judiciary only on the basis of wholly appropriate considerations, it will be important for him to remember that his own confidence in his own integrity is not, and cannot be regarded as, a guarantee.

It is with the same sentiment that a case for an international investment court is laid out here.

27 Starr v Ruxtom [2000] JC 208, 234 (also cited by Lord Bingham for the Privy Council in Millar v Dickson [2001] UKPC D4). 


\section{APPOINTMENT AND TENURE OF ADJUDICATORS RELEVANT PROVISIONS FOR SELECTED INTERNATIONAL COURTS AND TRIBUNALS}

\begin{tabular}{|c|c|c|c|c|c|c|c|}
\hline \multicolumn{8}{|c|}{ Regulatory - allows individual claims against state } \\
\hline Adjudicator & $\begin{array}{l}\text { Appointment } \\
\text { method }\end{array}$ & $\begin{array}{l}\text { Qualifications } \\
\text { and attributes }\end{array}$ & $\begin{array}{l}\text { Duration and } \\
\text { security of tenure }\end{array}$ & Qualities of tenure & $\begin{array}{l}\text { Eligibility for re- } \\
\text { appointment }\end{array}$ & $\begin{array}{l}\text { Method of appointment } \\
\text { to specific cases }\end{array}$ & Other provisions \\
\hline $\begin{array}{l}\text { European } \\
\text { Court of } \\
\text { Human Rights } \\
\text { - one judge per } \\
\text { High } \\
\text { Contracting } \\
\text { Party (ECHR } \\
\text { Art 22(1)). }\end{array}$ & $\begin{array}{l}\text { ECHR Art 22(1): } \\
\text { 'The judges shall be } \\
\text { elected by the } \\
\text { Parliamentary } \\
\text { Assembly with } \\
\text { respect to each } \\
\text { High Contracting } \\
\text { Party with by a } \\
\text { majority of votes } \\
\text { cast from a list of } \\
\text { three candidates } \\
\text { nominated by the } \\
\text { High Contracting } \\
\text { Party.' }\end{array}$ & $\begin{array}{l}\text { ECHR Art 21(1): } \\
\text { 'The judges shall be } \\
\text { of high moral } \\
\text { character and must } \\
\text { either possess the } \\
\text { qualifications } \\
\text { required for } \\
\text { appointment to } \\
\text { high judicial office } \\
\text { or be jurisconsults } \\
\text { of recognised } \\
\text { competence.' }\end{array}$ & $\begin{array}{l}\text { ECHR Art } 23 \text { (1): } \\
\text { 'The judges shall be } \\
\text { elected for a period } \\
\text { of six years....' } \\
\text { ECHR Art 23(6): } \\
\text { 'The terms of } \\
\text { office of judges } \\
\text { shall expire when } \\
\text { they reach the age } \\
\text { of } 70 . \text { ' } \\
\text { ECHR Art } 24: \text { 'No } \\
\text { judge may be } \\
\text { dismissed from his } \\
\text { office unless the } \\
\text { other judges decide } \\
\text { by a majority of } \\
\text { two-thirds that he } \\
\text { has ceased to fulfill } \\
\text { the required } \\
\text { conditions.' }\end{array}$ & $\begin{array}{l}\text { ECHR Art 21(3): 'During } \\
\text { their term of office the } \\
\text { judges shall not engage in } \\
\text { any activity which is } \\
\text { incompatible with their } \\
\text { independence, impartiality } \\
\text { or with the demands of a } \\
\text { full-time office; all questions } \\
\text { arising from the application } \\
\text { of this paragraph shall be } \\
\text { decided by the Court.' } \\
\text { Rules of the ECtHR, Rule } \\
\text { 4: 'In accordance with } \\
\text { Article 21(3) of the } \\
\text { Convention, the judges shall } \\
\text { not during their term of } \\
\text { office engage in any political } \\
\text { or administrative activity or } \\
\text { any professional activity } \\
\text { which is incompatible with } \\
\text { their independence or } \\
\text { impartiality or with the } \\
\text { demands of a full-time } \\
\text { office. Each judge shall } \\
\text { declare to the President of } \\
\text { the Court any additional } \\
\text { activity. In the event of a } \\
\text { disagreement between the } \\
\text { President and the judge } \\
\text { concerned, any question } \\
\text { arising shall be decided by } \\
\text { the plenary Court.' }\end{array}$ & $\begin{array}{l}\text { ECHR Art 23(1): } \\
\text { 'The judges shall be } \\
\text { elected for a period } \\
\text { of six years. They } \\
\text { may be re- } \\
\text { elected...' }\end{array}$ & $\begin{array}{l}\text { Rules of the ECtHR, Rule } \\
\text { 13: 'Judges of the Court } \\
\text { may not preside in cases in } \\
\text { which the Contracting Party } \\
\text { of which they are nationals } \\
\text { or in respect of which they } \\
\text { were elected is a party.' } \\
\text { Rules of the ECtHR, Rule } \\
\text { 24(2)(a): 'The Grand } \\
\text { Chamber shall include the } \\
\text { President and the Vice- } \\
\text { Presidents of the court and } \\
\text { the Presidents of the } \\
\text { Sections....' } \\
\text { Rules of the ECtHR, Rule } \\
24(2)(e): \text { 'The judges and } \\
\text { substitute judges who are to } \\
\text { complete the Grand } \\
\text { Chamber in each case } \\
\text { referred to it shall be } \\
\text { designated from among the } \\
\text { remaining judges by a } \\
\text { drawing of lots by the } \\
\text { President of the Court in } \\
\text { the presence of the } \\
\text { Registrar. The modalities } \\
\text { for the drawing of lots shall } \\
\text { be laid down by the Plenary } \\
\text { Court, having due regard to } \\
\text { the need for a } \\
\text { geographically balanced } \\
\text { composition reflected the } \\
\text { different legal systems } \\
\text { among the Contracting } \\
\text { Parties.' }\end{array}$ & $\begin{array}{l}\text { ECHR Art 21(2): 'The judges } \\
\text { shall sit on the Court in their } \\
\text { individual capacity.' } \\
\text { Rules of the ECtHR, Rule 3(1): } \\
\text { 'Before taking up office, each } \\
\text { elected judge shall... take the } \\
\text { following oath or make the } \\
\text { following solemn declaration: 'I } \\
\text { swear... that I will exercise my } \\
\text { functions as a judge honourably, } \\
\text { independently, and impartially } \\
\text { and that I will keep secret all } \\
\text { deliberations.' } \\
\text { Rules of the ECtHR, Rule } 28(2) \text { : } \\
\text { 'A judge may not take part in the } \\
\text { consideration of any case in } \\
\text { which he or she has a personal } \\
\text { interest or has previously acted } \\
\text { either as the Agent, advocate or } \\
\text { adviser of a party or of a person } \\
\text { having an interest in the case, or } \\
\text { as a member of a tribunal or } \\
\text { commission of inquiry, or in any } \\
\text { other capacity.' } \\
\text { Rules of the ECtHR, Rule } 28(4) \text { : } \\
\text { 'If the President of the Chamber } \\
\text { considers that a reason exists for } \\
\text { a judge to withdraw, he or she } \\
\text { shall consult with the judge } \\
\text { concerned; in the event of } \\
\text { disagreement, the Chamber shall } \\
\text { decide.' }\end{array}$ \\
\hline
\end{tabular}




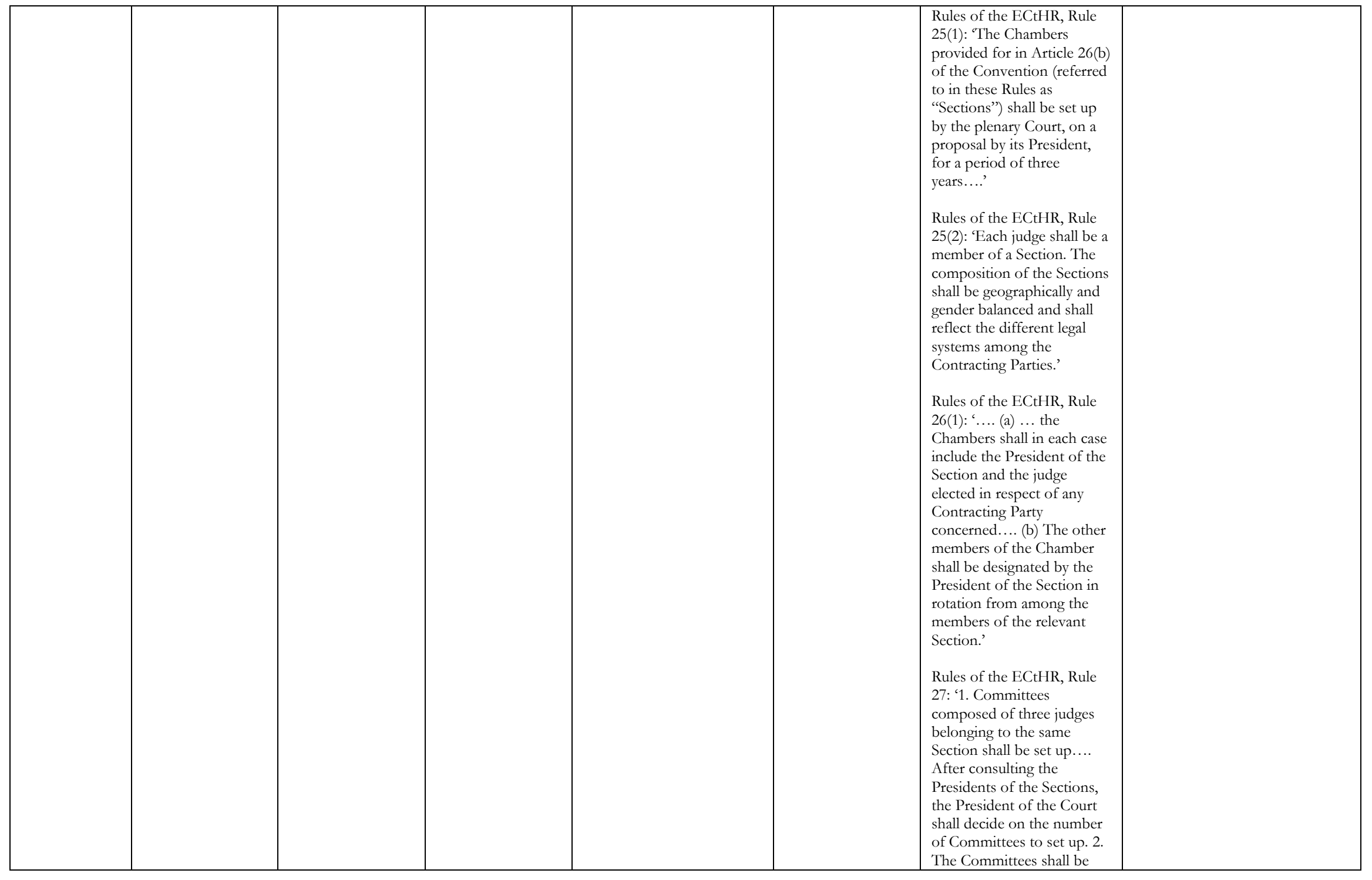




\begin{tabular}{|c|c|c|c|c|c|c|c|}
\hline & & & & & & $\begin{array}{l}\text { constituted for a period of } \\
\text { twelve months by rotation } \\
\text { among the members of } \\
\text { each Section, excepting the } \\
\text { President of the Section.' }\end{array}$ & \\
\hline Adjudicator & $\begin{array}{l}\text { Appointment } \\
\text { method }\end{array}$ & $\begin{array}{l}\text { Qualifications } \\
\text { and attributes }\end{array}$ & $\begin{array}{l}\text { Duration and } \\
\text { security of tenure }\end{array}$ & Qualities of tenure & $\begin{array}{l}\text { Eligibility for re- } \\
\text { appointment }\end{array}$ & $\begin{array}{l}\text { Method of appointment } \\
\text { to specific cases }\end{array}$ & Other provisions \\
\hline $\begin{array}{l}\text { European } \\
\text { Court of } \\
\text { Justice - one } \\
\text { judge per } \\
\text { Member State } \\
\text { (EU Treaty Art } \\
\text { 221) }\end{array}$ & $\begin{array}{l}\text { EU Treaty Art 223: } \\
\text { ‘... They shall be } \\
\text { appointed by } \\
\text { common accord of } \\
\text { the governments of } \\
\text { the Member } \\
\text { States....? }\end{array}$ & $\begin{array}{l}\text { EU Treaty Art 223: } \\
\text { 'The Judges... of } \\
\text { the Court of Justice } \\
\text { shall be chosen } \\
\text { from persons } \\
\text { whose } \\
\text { independence is } \\
\text { beyond doubt and } \\
\text { who possess the } \\
\text { qualifications } \\
\text { required for } \\
\text { appointment to the } \\
\text { highest judicial } \\
\text { offices in their } \\
\text { respective } \\
\text { countries or who } \\
\text { are jurisconsults of } \\
\text { recognised } \\
\text { competence....' }\end{array}$ & $\begin{array}{l}\text { EU Treaty Art 223: } \\
\text { '... they shall be } \\
\text { appointed by } \\
\text { common accord of } \\
\text { the governments of } \\
\text { the Member States } \\
\text { for a term of six } \\
\text { years.' }\end{array}$ & $\begin{array}{l}\text { Statute of the ECJ Art: } 4: \\
\text { 'The Judges may not hold } \\
\text { any political or } \\
\text { administrative office. They } \\
\text { may not engage in any } \\
\text { occupation, whether gainful } \\
\text { or not, unless exemption is } \\
\text { exceptionally granted by the } \\
\text { Council. When taking up } \\
\text { their duties, they shall give a } \\
\text { solemn undertaking that, } \\
\text { both during and after their } \\
\text { term of office, they will } \\
\text { respect the obligations } \\
\text { arising therefrom, in } \\
\text { particular the duty to } \\
\text { behave with integrity and } \\
\text { discretion as regards the } \\
\text { acceptance, after they have } \\
\text { ceased to hold office, of } \\
\text { certain appointments or } \\
\text { benefits. Any doubt on this } \\
\text { point shall be settled by } \\
\text { decision of the Court.' } \\
\text { Code of Conduct of the } \\
\text { ECJ Art 5: 'Members who } \\
\text { wish to take part in an } \\
\text { external activity shall } \\
\text { request prior authorisation } \\
\text { from the Court or Tribunal } \\
\text { of which they are a } \\
\text { Member. They shall } \\
\text { undertake, however, to } \\
\text { comply with their obligation } \\
\text { to be available so as to } \\
\text { devote themselves fully to } \\
\text { the performance of their } \\
\text { duties.' }\end{array}$ & $\begin{array}{l}\text { EU Treaty Art 223: } \\
\text { 'Retiring Judges... } \\
\text { may be } \\
\text { reappointed.' }\end{array}$ & $\begin{array}{l}\text { Rules of Procedure of the } \\
\text { ECJ, Art 6: 'Judges... shall } \\
\text { rank equally in precedent } \\
\text { according to their seniority } \\
\text { in office. Where there is } \\
\text { equal seniority in office, } \\
\text { precedence shall be } \\
\text { determined by age.' } \\
\text { Rules of Procedure of the } \\
\text { ECJ, Art } 11 b(1): \text { 'For each } \\
\text { case the Grand Chamber } \\
\text { shall be composed of the } \\
\text { President of the Court, the } \\
\text { Presidents of the Chambers } \\
\text { of five Judges, the Judge- } \\
\text { Rapporteur and the number } \\
\text { of Judges necessary to reach } \\
\text { 13. The last mentioned } \\
\text { Judges shall be designated } \\
\text { from the list referred to in } \\
\text { paragraph } 2, \text { following the } \\
\text { order laid down therein....' } \\
\text { Rules of Procedure of the } \\
\text { ECJ, Art } 11 b(2): \text { '... a list of } \\
\text { the other Judges shall be } \\
\text { drawn up for the purposes } \\
\text { of determining the } \\
\text { composition of the Grand } \\
\text { Chamber. That list shall } \\
\text { follow the order laid down } \\
\text { in Article } 6 \text { of these Rules, } \\
\text { alternating with the reverse } \\
\text { order....' } \\
\text { Rules of Procedure of the } \\
\text { ECJ, Art } 11 \mathrm{c}(2) \text { : 'For the } \\
\text { composition of the }\end{array}$ & $\begin{array}{l}\text { Statute of the ECJ Art: 2: 'Before } \\
\text { taking up his duties each Judge } \\
\text { shall, in open court, take an oath } \\
\text { to perform his duties impartially } \\
\text { and conscientiously and to } \\
\text { preserve the secrecy of all the } \\
\text { deliberations of the Court.' } \\
\text { Statute of the ECJ Art: 6: 'A } \\
\text { Judge may be deprived of his } \\
\text { office or of his right to a pension } \\
\text { or other benefits in its stead only } \\
\text { if, in the unanimous opinion of } \\
\text { the Judges and Advocates } \\
\text { General of the Court, he no } \\
\text { longer fulfils the requisite } \\
\text { conditions or meets the } \\
\text { obligations arising from his office. } \\
\text { The Judge concerned shall not } \\
\text { take part in any such } \\
\text { deliberations.' } \\
\text { Statute of the ECJ Art: } 15: \text { 'The } \\
\text { Court shall remain permanently in } \\
\text { session. The duration of the } \\
\text { judicial vacations shall be } \\
\text { determined by the Court with due } \\
\text { regard to the needs of its } \\
\text { business.' } \\
\text { Statute of the ECJ Art: } 18: \text { : No } \\
\text { Judge or Advocate General may } \\
\text { take part in the disposal of any } \\
\text { case in which he has previously } \\
\text { taken part as agent or adviser or } \\
\text { has acted for one of the parties, } \\
\text { or in which he has been called } \\
\text { upon to pronounce as a member } \\
\text { of a court or tribunal, of a }\end{array}$ \\
\hline
\end{tabular}




\begin{tabular}{|c|c|c|c|c|c|c|c|}
\hline & & & & & & $\begin{array}{l}\text { Chambers of five Judges... } \\
\text { those lists shall be drawn up } \\
\text { including all the Judges to } \\
\text { the Chamber concerned.... } \\
\text { in the same way as the list } \\
\text { referred to in Article } 11 \mathrm{~b}(2) \text {. } \\
\text { For the composition of the } \\
\text { Chambers of three } \\
\text { Judges... those Chamber } \\
\text { lists shall be drawn up } \\
\text { including all the Judges } \\
\text { attached to the Chamber } \\
\text { concerned.... The lists shall } \\
\text { be drawn up according to } \\
\text { the order laid down in } \\
\text { Article } 6 \text { of these Rules.' }\end{array}$ & $\begin{array}{l}\text { commission of inquiry or in any } \\
\text { other capacity.... If, for some } \\
\text { special reason, the President } \\
\text { considers that any Judge or } \\
\text { Advocate General should not sit } \\
\text { or make submissions in a } \\
\text { particular case, he shall notify him } \\
\text { accordingly. Any difficulty arising } \\
\text { as to the application of this } \\
\text { Article shall be settled by decision } \\
\text { of the Court.' } \\
\text { Code of Conduct of the ECJ Art } \\
\text { 3: 'Members shall not accept gifts } \\
\text { of any kind which might call into } \\
\text { question their independence.' } \\
\text { Code of Conduct of the ECJ Art } \\
\text { 3: 'Members shall avoid any } \\
\text { situation which may give rise to a } \\
\text { conflict of interest.' } \\
\text { Code of Conduct of the ECJ Art } \\
\text { 6: '... Members shall } \\
\text { undertake.... that, for a period of } \\
\text { three years from the date of their } \\
\text { ceasing to hold office, they will } \\
\text { not act - as representatives of } \\
\text { parties, in either written or oral } \\
\text { pleadings, in cases before the } \\
\text { Community judicature.' }\end{array}$ \\
\hline Adjudicator & $\begin{array}{l}\text { Appointment } \\
\text { method }\end{array}$ & $\begin{array}{l}\text { Qualifications } \\
\text { and attributes }\end{array}$ & $\begin{array}{l}\text { Duration and } \\
\text { security of tenure }\end{array}$ & Qualities of tenure & $\begin{array}{l}\text { Eligibility for re- } \\
\text { appointment }\end{array}$ & $\begin{array}{l}\text { Method of appointment } \\
\text { to specific cases }\end{array}$ & Other provisions \\
\hline $\begin{array}{l}\text { European } \\
\text { Court of First } \\
\text { Instance }-27 \\
\text { judges (Statute } \\
\text { of the ECJ Art } \\
\text { 48; EU Treaty } \\
\text { Art 224) }\end{array}$ & $\begin{array}{l}\text { EU Treaty Art 223: } \\
\text { '... They shall be } \\
\text { appointed by } \\
\text { common accord of } \\
\text { the governments of } \\
\text { the Member } \\
\text { States...? }\end{array}$ & $\begin{array}{l}\text { EU Treaty Art 224: } \\
\text { 'The members of } \\
\text { the Court of First } \\
\text { Instance shall be } \\
\text { chosen from } \\
\text { persons whose } \\
\text { independence is } \\
\text { beyond doubt and } \\
\text { who possess the } \\
\text { ability required for } \\
\text { appointment to } \\
\text { high judicial } \\
\text { office....' }\end{array}$ & $\begin{array}{l}\text { EU Treaty Art 224: } \\
\text { ‘... They shall be } \\
\text { appointed by } \\
\text { common accord of } \\
\text { the governments of } \\
\text { the Member States } \\
\text { for a term of six } \\
\text { years.... }\end{array}$ & $\begin{array}{l}\text { Statute of the ECJ Art: } 4 \\
\text { and } 47: \text { 'The Judges may } \\
\text { not hold any political or } \\
\text { administrative office. They } \\
\text { may not engage in any } \\
\text { occupation, whether gainful } \\
\text { or not, unless exemption is } \\
\text { exceptionally granted by the } \\
\text { Council. When taking up } \\
\text { their duties, they shall give a } \\
\text { solemn undertaking that, } \\
\text { both during and after their } \\
\text { term of office, they will } \\
\text { respect the obligations }\end{array}$ & $\begin{array}{l}\text { EU Treaty Art 224: } \\
\text { 'Retiring members } \\
\text { shall be eligible for } \\
\text { re-appointment.' }\end{array}$ & $\begin{array}{l}\text { Rules of Procedure of the } \\
\text { Court of First Instance, Art } \\
\text { 6: 'With the exception of } \\
\text { the President of the Court } \\
\text { of First Instance and of the } \\
\text { Presidents of the Chambers, } \\
\text { the Judges shall rank equally } \\
\text { in precedence according to } \\
\text { their seniority in office. } \\
\text { Where there is equal } \\
\text { seniority in office, } \\
\text { precedence shall be } \\
\text { determined by age....' }\end{array}$ & $\begin{array}{l}\text { Statute of the ECJ Art: } 2 \text { and } 47 \text { : } \\
\text { 'Before taking up his duties each } \\
\text { Judge shall, in open court, take an } \\
\text { oath to perform his duties } \\
\text { impartially and conscientiously } \\
\text { and to preserve the secrecy of all } \\
\text { the deliberations of the Court.' } \\
\text { Statute of the ECJ Art: } 6 \text { and } 47 \text { : } \\
\text { 'A Judge may be deprived of his } \\
\text { office or of his right to a pension } \\
\text { or other benefits in its stead only } \\
\text { if, in the unanimous opinion of } \\
\text { the Judges and Advocates }\end{array}$ \\
\hline
\end{tabular}




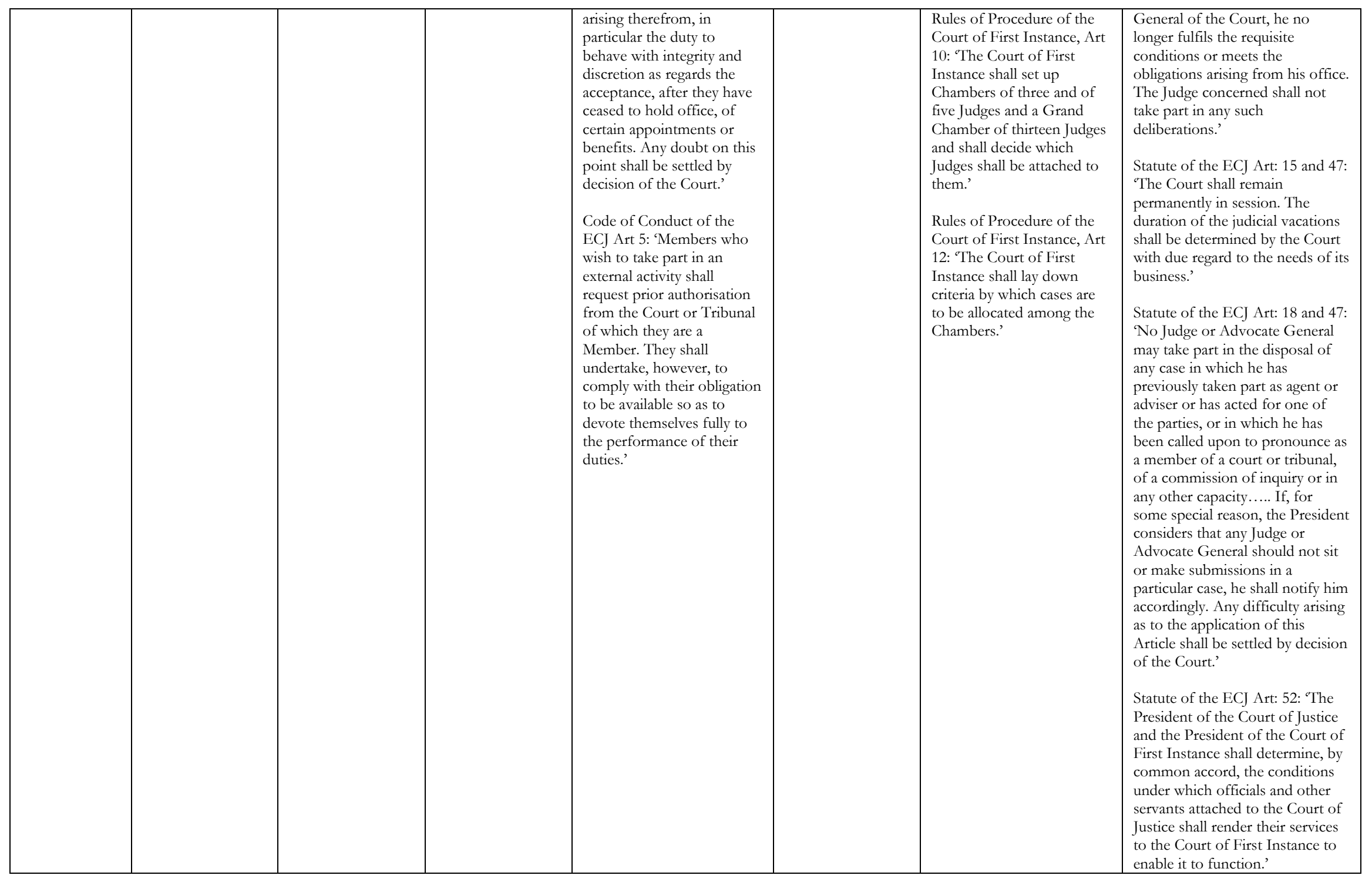




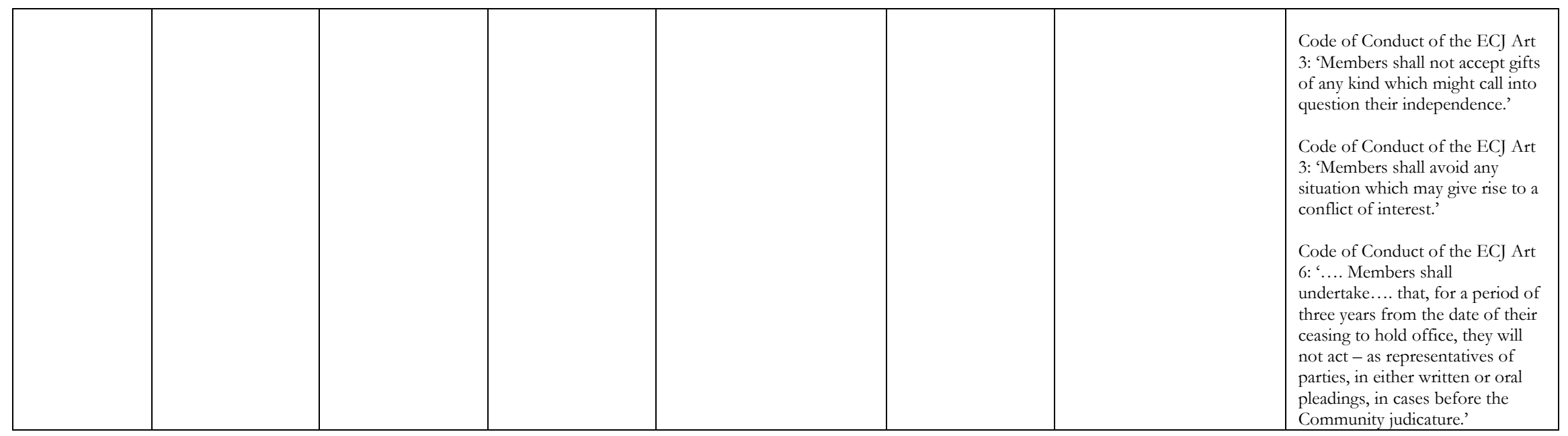




\begin{tabular}{|c|c|c|c|c|c|c|c|}
\hline \multicolumn{8}{|c|}{ Regulatory - allows state claims against individual } \\
\hline Adjudicator & $\begin{array}{l}\text { Appointment } \\
\text { method }\end{array}$ & $\begin{array}{l}\text { Qualifications } \\
\text { and attributes }\end{array}$ & $\begin{array}{l}\text { Duration and } \\
\text { security of tenure }\end{array}$ & Qualities of tenure & $\begin{array}{l}\text { Eligibility for re- } \\
\text { appointment }\end{array}$ & $\begin{array}{l}\text { Method of appointment } \\
\text { to specific cases }\end{array}$ & Other provisions \\
\hline $\begin{array}{l}\text { International } \\
\text { Criminal Court } \\
\text { - at least } 18 \\
\text { judges (Rome } \\
\text { Statute Art } \\
\text { 36(1)). }\end{array}$ & $\begin{array}{l}\text { Rome Statute Art } \\
35(1): \text { 'All judges } \\
\text { shall be elected as } \\
\text { full-time members } \\
\text { of the Court...' } \\
\text { Rome Statute Art } \\
36 \text { (4)(a): } \\
\text { 'Nominations of } \\
\text { candidates for } \\
\text { election to the } \\
\text { Court may be made } \\
\text { by any State Party } \\
\text { to this Statute, and } \\
\text { shall be made } \\
\text { either: (i) By the } \\
\text { procedure for the } \\
\text { nomination of } \\
\text { candidates for } \\
\text { appointment to the } \\
\text { highest judicial } \\
\text { offices in the State } \\
\text { in question; or (ii) } \\
\text { By the procedure } \\
\text { provided for the } \\
\text { nomination of } \\
\text { candidates for the } \\
\text { International Court } \\
\text { of Justice in the } \\
\text { Statute of that } \\
\text { Court. } \\
\text { Nominations shall } \\
\text { be accompanied by } \\
\text { a statement in the } \\
\text { necessary detail } \\
\text { specifying how the } \\
\text { candidate fulfils the } \\
\text { requirements of } \\
\text { paragraph 3.' } \\
\text { Rome Statute Art }\end{array}$ & $\begin{array}{l}\text { Rome Statute Art } \\
36(3)(a) \text { : 'The } \\
\text { judges shall be } \\
\text { chosen from } \\
\text { among persons of } \\
\text { high moral } \\
\text { character, } \\
\text { impartiality and } \\
\text { integrity who } \\
\text { possess the } \\
\text { qualifications } \\
\text { required in their } \\
\text { respective States } \\
\text { for appointment to } \\
\text { the highest judicial } \\
\text { offices.' } \\
\\
\text { Rome Statute Art } \\
36(3) \text { (b): 'Every } \\
\text { candidate for } \\
\text { election to the } \\
\text { Court shall: (i) } \\
\text { Have established } \\
\text { competence in } \\
\text { criminal law and } \\
\text { procedure, and the } \\
\text { necessary relevant } \\
\text { experience, } \\
\text { whether as judge, } \\
\text { prosecutor, } \\
\text { advocate or in } \\
\text { other similar } \\
\text { capacity in criminal } \\
\text { proceedings; or (ii) } \\
\text { Have established } \\
\text { competence in } \\
\text { relevant areas of } \\
\text { international law } \\
\text { such as } \\
\text { international } \\
\text { humanitarian law }\end{array}$ & $\begin{array}{l}\text { Rome Statute Art } \\
\text { 36(9)(a): '... judges } \\
\text { shall hold office for } \\
\text { a term of nine } \\
\text { years....' } \\
\text { Rome Statute Art } \\
\text { 46(1): 'A judge... } \\
\text { shall be removed } \\
\text { from office if a } \\
\text { decision to this } \\
\text { effect is made in } \\
\text { accordance with } \\
\text { paragraph } 2 \text {, in } \\
\text { cases where that } \\
\text { person: (a) Is } \\
\text { found to have } \\
\text { committed serious } \\
\text { misconduct or a } \\
\text { serious breach of } \\
\text { his or her duties } \\
\text { under this } \\
\text { Statute...; or (b) Is } \\
\text { unable to exercise } \\
\text { the functions } \\
\text { required by this } \\
\text { Statute.' } \\
\text { Rome Statute Art } \\
46(2): \text { 'A decision } \\
\text { as to the removal } \\
\text { from office of a } \\
\text { judge... shall be } \\
\text { made by the } \\
\text { Assembly of State } \\
\text { Parties, by secret } \\
\text { ballot:: (a) In the } \\
\text { case of a judge, by } \\
\text { a two-thirds } \\
\text { majority of the } \\
\text { States Parties upon }\end{array}$ & 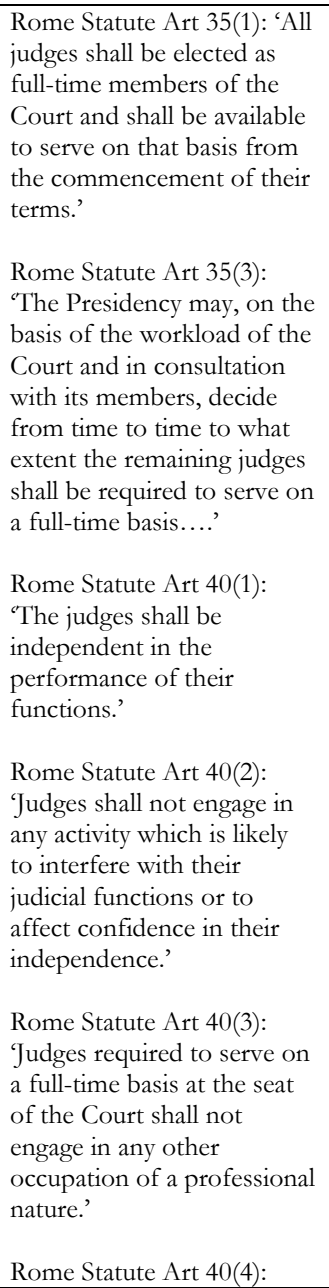 & $\begin{array}{l}\text { Rome Statute Art } \\
36(9)(a): \text { : ... judges } \\
\text { shall... not be } \\
\text { eligible for re- } \\
\text { election.' }\end{array}$ & $\begin{array}{l}\text { Rome Statute Art 39(1): 'As } \\
\text { soon as possible after the } \\
\text { election of the judges, the } \\
\text { Court shall organize itself } \\
\text { into the divisions } \\
\text { specified.... The assignment } \\
\text { of judges to divisions shall } \\
\text { be based on the nature of } \\
\text { the functions to be } \\
\text { performed by each division } \\
\text { and the qualifications and } \\
\text { experience of the judges } \\
\text { elected to the Court, in such } \\
\text { a way that each division } \\
\text { shall contain an appropriate } \\
\text { combination of expertise in } \\
\text { criminal law and procedure } \\
\text { and in international law. } \\
\text { The Trial and Pre-Trial } \\
\text { Divisions shall be } \\
\text { composed predominantly of } \\
\text { judges with criminal trial } \\
\text { experience.' }\end{array}$ & $\begin{array}{l}\text { Rome Statute Art 41(2)(a): 'A } \\
\text { judge shall not participate in any } \\
\text { case in which his or her } \\
\text { impartiality might reasonably be } \\
\text { doubted on any ground. A judge } \\
\text { shall be disqualified from a case in } \\
\text { accordance with this paragraph if, } \\
\text { inter alia, that judge has } \\
\text { previously been involved in any } \\
\text { capacity in that case before the } \\
\text { Court or in a related criminal case } \\
\text { at the national level involving the } \\
\text { person being investigated or } \\
\text { prosecuted....' } \\
\text { Rome Statute Art } 41(2)(\mathrm{c}): \text { 'Any } \\
\text { question as to the disqualification } \\
\text { of a judge shall be decided by an } \\
\text { absolute majority of the judges. } \\
\text { The challenged judge shall be } \\
\text { entitled to present his or her } \\
\text { comments on the matter, but } \\
\text { shall not take part in the decision.' } \\
\text { Rome Statute Art } 45: \text { 'Before } \\
\text { taking up their respective duties } \\
\text { under this Statute, the judges... } \\
\text { shall each make a solemn } \\
\text { undertaking in open court to } \\
\text { exercise his or her respective } \\
\text { functions impartially and } \\
\text { conscientiously.' } \\
\text { Rome Statute Art } 49: \text { 'The } \\
\text { judges... shall receive such } \\
\text { salaries, allowances and expenses } \\
\text { as may be decided upon by the } \\
\text { Assembly of States Parties. These } \\
\text { salaries and allowances shall not } \\
\text { be reduced during their terms of } \\
\text { office.' }\end{array}$ \\
\hline
\end{tabular}




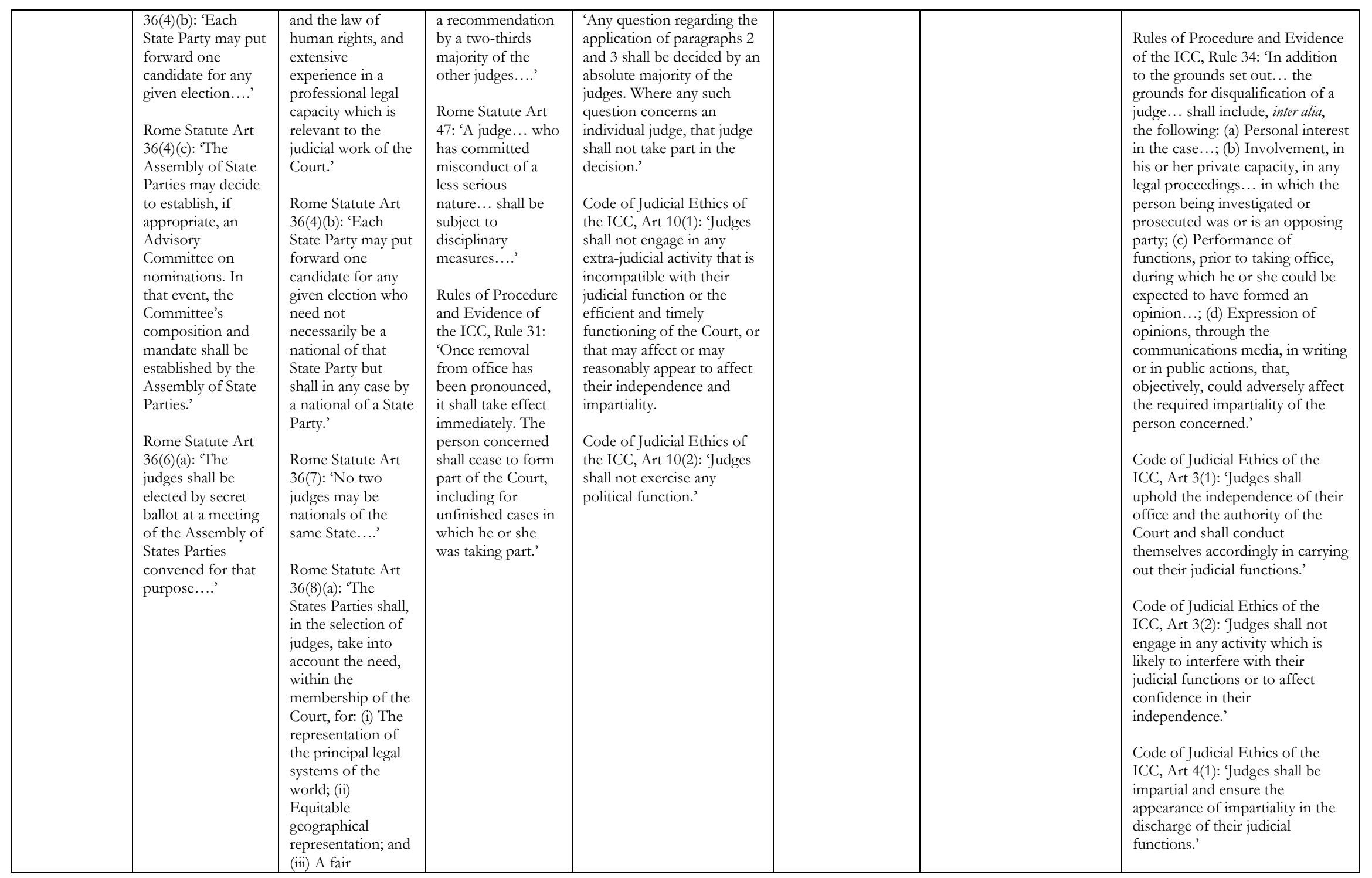




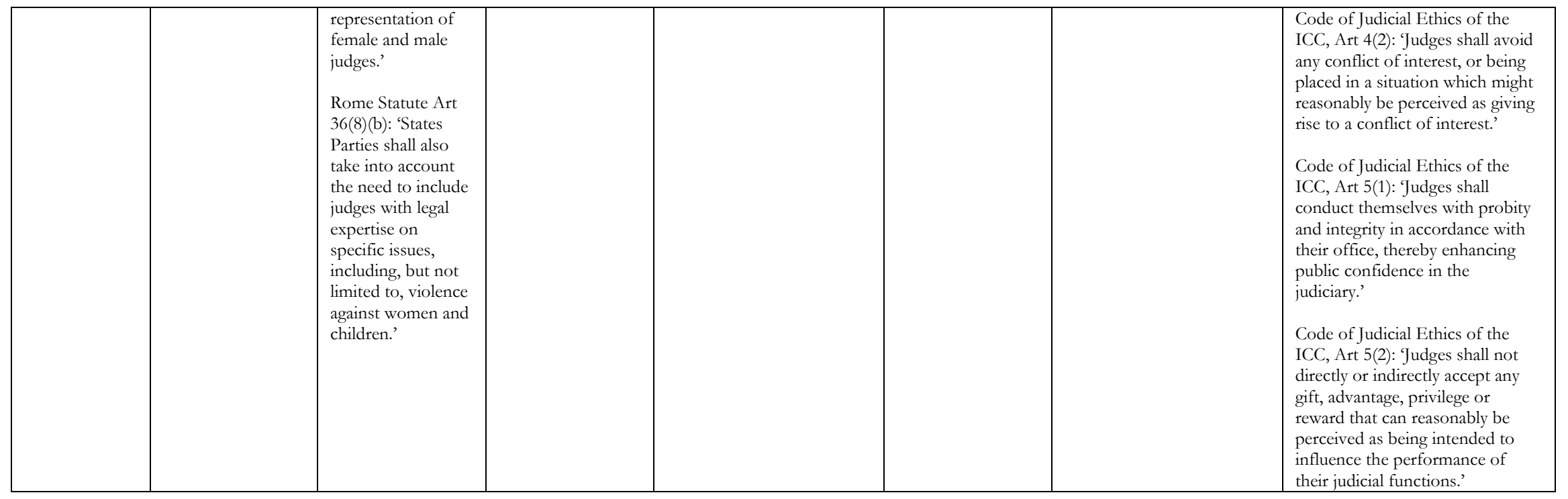




\begin{tabular}{|c|c|c|c|c|c|c|c|}
\hline \multicolumn{8}{|c|}{ Reciprocal - limited to inter-state disputes } \\
\hline Adjudicator & $\begin{array}{l}\text { Appointment } \\
\text { method }\end{array}$ & $\begin{array}{l}\text { Qualifications } \\
\text { and attributes }\end{array}$ & $\begin{array}{l}\text { Duration and } \\
\text { security of tenure }\end{array}$ & Qualities of tenure & $\begin{array}{l}\text { Eligibility for re- } \\
\text { appointment }\end{array}$ & $\begin{array}{l}\text { Method of appointment } \\
\text { to specific cases }\end{array}$ & Other provisions \\
\hline $\begin{array}{l}\text { International } \\
\text { Court of } \\
\text { Justice - } 15 \\
\text { judges (ICJ } \\
\text { Statute Art } \\
\text { 3(1)). }\end{array}$ & $\begin{array}{l}\text { ICJ Statute Art 4: } \\
\text { 'The members of } \\
\text { the Court shall be } \\
\text { elected by the } \\
\text { General Assembly } \\
\text { and by the Security } \\
\text { Council from a list } \\
\text { of persons } \\
\text { nominated by the } \\
\text { national groups in } \\
\text { the Permanent } \\
\text { Court of } \\
\text { Arbitration...' } \\
\text { ICJ Statute Art } 8: \\
\text { 'The General } \\
\text { Assembly and the } \\
\text { Security Council } \\
\text { shall proceed } \\
\text { independently of } \\
\text { one another to } \\
\text { elect the members } \\
\text { of the Court.' } \\
\text { ICJ Statute Art 10: } \\
\text { '1. Those } \\
\text { candidates who } \\
\text { obtain an absolute } \\
\text { majority of votes in } \\
\text { the General } \\
\text { Assembly and in } \\
\text { the Security } \\
\text { Council shall be } \\
\text { considered as } \\
\text { elected. } 2 \text {. Any vote } \\
\text { of the Security } \\
\text { Council, whether } \\
\text { for the election of } \\
\text { judges or..., shall } \\
\text { be taken without } \\
\text { any distinction }\end{array}$ & $\begin{array}{l}\text { ICJ Statute Art 2: } \\
\text { 'The Court shall be } \\
\text { composed of a } \\
\text { body of } \\
\text { independent } \\
\text { judges, elected } \\
\text { regardless of their } \\
\text { nationality from } \\
\text { among persons of } \\
\text { high moral } \\
\text { character, who } \\
\text { possess the } \\
\text { qualifications } \\
\text { required in their } \\
\text { respective } \\
\text { countries for } \\
\text { appointment to the } \\
\text { highest judicial } \\
\text { offices, or are } \\
\text { jurisconsults of } \\
\text { recognized } \\
\text { competence in } \\
\text { international law.' } \\
\text { ICj Statute Art } \\
3(1): \text { 'The Court } \\
\text { shall consist of } \\
\text { fifteen members, } \\
\text { no two of whom } \\
\text { may be nationals of } \\
\text { the same state.' } \\
\text { ICJ Statute Art 9: } \\
\text { 'At every election, } \\
\text { the electors shall } \\
\text { bear in mind not } \\
\text { only that the } \\
\text { persons to be } \\
\text { elected should } \\
\text { individually possess } \\
\text { the qualifications }\end{array}$ & $\begin{array}{l}\text { ICJ Statute Art } \\
\text { 13(1): 'The } \\
\text { members of the } \\
\text { Court shall be } \\
\text { elected for nine } \\
\text { years...' } \\
\text { ICJ Statute Art } \\
\text { 18(1): 'No member } \\
\text { of the Court can be } \\
\text { dismissed unless, in } \\
\text { the unanimous } \\
\text { opinion of the } \\
\text { other members, he } \\
\text { has ceased to fulfill } \\
\text { the required } \\
\text { conditions.' }\end{array}$ & $\begin{array}{l}\text { ICJ Statute Art 16: ' } 1 \text {. No } \\
\text { member of the Court may } \\
\text { exercise any political or } \\
\text { administrative function, or } \\
\text { engage in any other } \\
\text { occupation of a professional } \\
\text { nature. } 2 \text {. Any doubt on this } \\
\text { point shall be settled by the } \\
\text { decision of the Court.' } \\
\text { ICJ Statute Art 23(3): } \\
\text { 'Members of the Court shall } \\
\text { be bound, unless they are } \\
\text { on leave or prevented from } \\
\text { attending by illness or other } \\
\text { serious reasons duly } \\
\text { explained to the President, } \\
\text { to hold themselves } \\
\text { permanently at the disposal } \\
\text { of the Court.' }\end{array}$ & $\begin{array}{l}\text { ICJ Statute Art } \\
13(1):^{\circ} \text { 'The } \\
\text { members of the } \\
\text { Court... may be re- } \\
\text { elected...' }\end{array}$ & $\begin{array}{l}\text { ICJ Statute Art 26: '1. The } \\
\text { Court may from time to } \\
\text { time form on or more } \\
\text { chambers, composed of } \\
\text { three or more judges as the } \\
\text { Court may determine.... } 2 \text {. } \\
\text { The Court may at any time } \\
\text { form a chamber for dealing } \\
\text { with a particular case. The } \\
\text { number of judges to } \\
\text { constitute such a chamber } \\
\text { shall be determined by the } \\
\text { Court with the approval of } \\
\text { the parties.' } \\
\text { Rules of the Court, Art } \\
\text { 18(1): 'Elections to all } \\
\text { Chambers shall take place } \\
\text { by secret ballot. The } \\
\text { Members of the Court } \\
\text { obtaining the largest } \\
\text { number of votes } \\
\text { constituting a majority of } \\
\text { the Members of the Court } \\
\text { composing it at the time of } \\
\text { the election shall be } \\
\text { declared elected.' }\end{array}$ & $\begin{array}{l}\text { ICJ Statute Art 17: '1. No } \\
\text { member of the Court may act as } \\
\text { agent, counsel, or advocate in any } \\
\text { case.... 3. Any doubt on this } \\
\text { point shall be settled by the } \\
\text { decision of the Court.' } \\
\text { ICJ Statute Art 20: 'Every } \\
\text { member of the Court shall, before } \\
\text { taking up his duties, make a } \\
\text { solemn declaration in open court } \\
\text { that he will exercise his powers } \\
\text { impartially and conscientiously.' } \\
\text { ICJ Statute Art } 23(1): \text { 'The Court } \\
\text { shall remain permanently in } \\
\text { session, except during the judicial } \\
\text { vacations, the dates and duration } \\
\text { of which shall be fixed by the } \\
\text { Court.' } \\
\text { ICJ Statute Art } 24: \text { “.... } 2 . \text { If the } \\
\text { President considers that for some } \\
\text { special reason one of the } \\
\text { members of the Court should not } \\
\text { sit in a particular case, he shall } \\
\text { give him notice accordingly. } 3 . \text { If } \\
\text { in any such case the member of } \\
\text { the Court and the President } \\
\text { disagree, the matter shall be } \\
\text { settled by the decision of the } \\
\text { Court.' } \\
\text { ICJ Statute Art } 32: \text { ' } 1 . \text { Each } \\
\text { member of the Court shall receive } \\
\text { an annual salary.... } 5 . \text { These } \\
\text { salaries, allowances, and } \\
\text { compensation shall be fixed by } \\
\text { the General Assembly. They may } \\
\text { not be decreased during the term } \\
\text { of office.... } 7 . \text { Regulations made }\end{array}$ \\
\hline
\end{tabular}




\begin{tabular}{|c|c|c|c|c|c|c|c|}
\hline & $\begin{array}{l}\text { between permanent } \\
\text { and non- } \\
\text { permanent } \\
\text { members of the } \\
\text { Security Council. } \\
\text { 3....? }\end{array}$ & $\begin{array}{l}\text { required, but also } \\
\text { that in the body as } \\
\text { a whole the } \\
\text { representation of } \\
\text { the main forms of } \\
\text { civilization and of } \\
\text { the principal legal } \\
\text { systems of the } \\
\text { world should be } \\
\text { assured.' }\end{array}$ & & & & & $\begin{array}{l}\text { by the General Assembly shall fix } \\
\text { the conditions under which } \\
\text { retirement pensions may be given } \\
\text { to members of the Court....? }\end{array}$ \\
\hline Adjudicator & $\begin{array}{l}\text { Appointment } \\
\text { method }\end{array}$ & $\begin{array}{l}\text { Qualifications } \\
\text { and attributes }\end{array}$ & $\begin{array}{l}\text { Duration and } \\
\text { security of tenure }\end{array}$ & Qualities of tenure & $\begin{array}{l}\text { Eligibility for re- } \\
\text { appointment }\end{array}$ & $\begin{array}{l}\text { Method of appointment } \\
\text { to specific cases }\end{array}$ & Other provisions \\
\hline $\begin{array}{l}\text { WTO } \\
\text { Appellate Body } \\
\text { - seven } \\
\text { members, of } \\
\text { whom three } \\
\text { serve on any } \\
\text { one case (DSU } \\
\text { Art 17(1)). }\end{array}$ & $\begin{array}{l}\text { DSU Art 17(2): } \\
\text { 'The DSB shall } \\
\text { appoint persons to } \\
\text { serve on the } \\
\text { Appellate Body....' }\end{array}$ & $\begin{array}{l}\text { DSU Art 17(3) } \\
\text { 'The Appellate } \\
\text { Body shall } \\
\text { comprise persons } \\
\text { of recognized } \\
\text { authority, with } \\
\text { demonstrated } \\
\text { expertise in law, } \\
\text { international trade } \\
\text { and the subject } \\
\text { matter of the } \\
\text { covered } \\
\text { agreements } \\
\text { generally....' } \\
\text { DSU Art 17(3): } \\
\text { '... The Appellate } \\
\text { Body membership } \\
\text { shall be broadly } \\
\text { representative of } \\
\text { membership in the } \\
\text { WTO....' }\end{array}$ & $\begin{array}{l}\text { DSU Art 17(2): } \\
\text { 'The DSB shall } \\
\text { appoint persons to } \\
\text { serve on the } \\
\text { Appellate Body for } \\
\text { a four-year term... } \\
\text { However, the } \\
\text { terms of three of } \\
\text { the seven persons } \\
\text { appointed } \\
\text { immediately after } \\
\text { the entry into force } \\
\text { of the WTO } \\
\text { Agreement shall } \\
\text { expire at the end of } \\
\text { two years, to be } \\
\text { determined by lot. } \\
\text { Vacancies shall be } \\
\text { filled as they } \\
\text { arise.... }\end{array}$ & $\begin{array}{l}\text { DSU Art } 17(3): \text { ‘.... All } \\
\text { persons serving on the } \\
\text { Appellate Body shall be } \\
\text { available at all times and on } \\
\text { short notice, and shall stay } \\
\text { abreast of dispute } \\
\text { settlement activities and } \\
\text { other relevant activities of } \\
\text { the WTO. They shall not } \\
\text { participate in the } \\
\text { consideration of any } \\
\text { disputes that would create a } \\
\text { direct or indirect conflict of } \\
\text { interest.' }\end{array}$ & $\begin{array}{l}\text { DSU Art 17(2): } \\
\text { 'The DSB shall } \\
\text { appoint persons to } \\
\text { serve on the } \\
\text { Appellate Body for } \\
\text { a four-year term, } \\
\text { and each person } \\
\text { may be } \\
\text { reappointed } \\
\text { once....' }\end{array}$ & $\begin{array}{l}\text { DSU Art 17(1): ‘... Persons } \\
\text { serving on the Appellate } \\
\text { Body shall serve in rotation. } \\
\text { Such rotation shall be } \\
\text { determined in the working } \\
\text { procedures of the Appellate } \\
\text { Body.' }\end{array}$ & $\begin{array}{l}\text { DSU Art 17(3): 'The Appellate } \\
\text { Body shall comprise persons... } \\
\text { unaffiliated with any } \\
\text { government...' } \\
\text { DSU Art 17(3) 'They shall not } \\
\text { participate in the consideration of } \\
\text { any disputes that would create a } \\
\text { direct or indirect conflict of } \\
\text { interest.' }\end{array}$ \\
\hline $\begin{array}{l}\text { WTO panels - } \\
\text { three members } \\
\text { unless parties } \\
\text { agree to have } \\
\text { five (DSU Art } \\
\text { 8(5)). }\end{array}$ & NA & $\begin{array}{l}\text { DSU Art } 8(1)- \\
\text { Panels shall be } \\
\text { composed of well- } \\
\text { qualified } \\
\text { governmental } \\
\text { and/or non- } \\
\text { governmental } \\
\text { individuals, } \\
\text { including persons } \\
\text { who have served } \\
\text { on or presented a } \\
\text { case to a panel, } \\
\text { served as a } \\
\end{array}$ & NA & NA & NA & $\begin{array}{l}\text { DSU Art 8(6): 'The } \\
\text { Secretariat shall propose } \\
\text { nominations for the panel } \\
\text { to the parties to the dispute. } \\
\text { The parties to the dispute } \\
\text { shall not oppose } \\
\text { nominations except for } \\
\text { compelling reasons.' } \\
\text { DSU Art } 8(7) \text { : 'If there is no } \\
\text { agreement on the panelists } \\
\text { within } 20 \text { days after the date } \\
\text { of the establishment of a }\end{array}$ & $\begin{array}{l}\text { DSU Art 8(2) 'Panel members } \\
\text { should be selected with a view to } \\
\text { ensuring the independence of the } \\
\text { members, a sufficiently diverse } \\
\text { background and a wide spectrum } \\
\text { of experience.' } \\
\text { DSU Art 8(3): Citizens of } \\
\text { Members whose governments are } \\
\text { parties to the dispute or third } \\
\text { parties... shall not serve on a } \\
\text { panel concerned with that } \\
\text { dispute, unless the parties to the }\end{array}$ \\
\hline
\end{tabular}




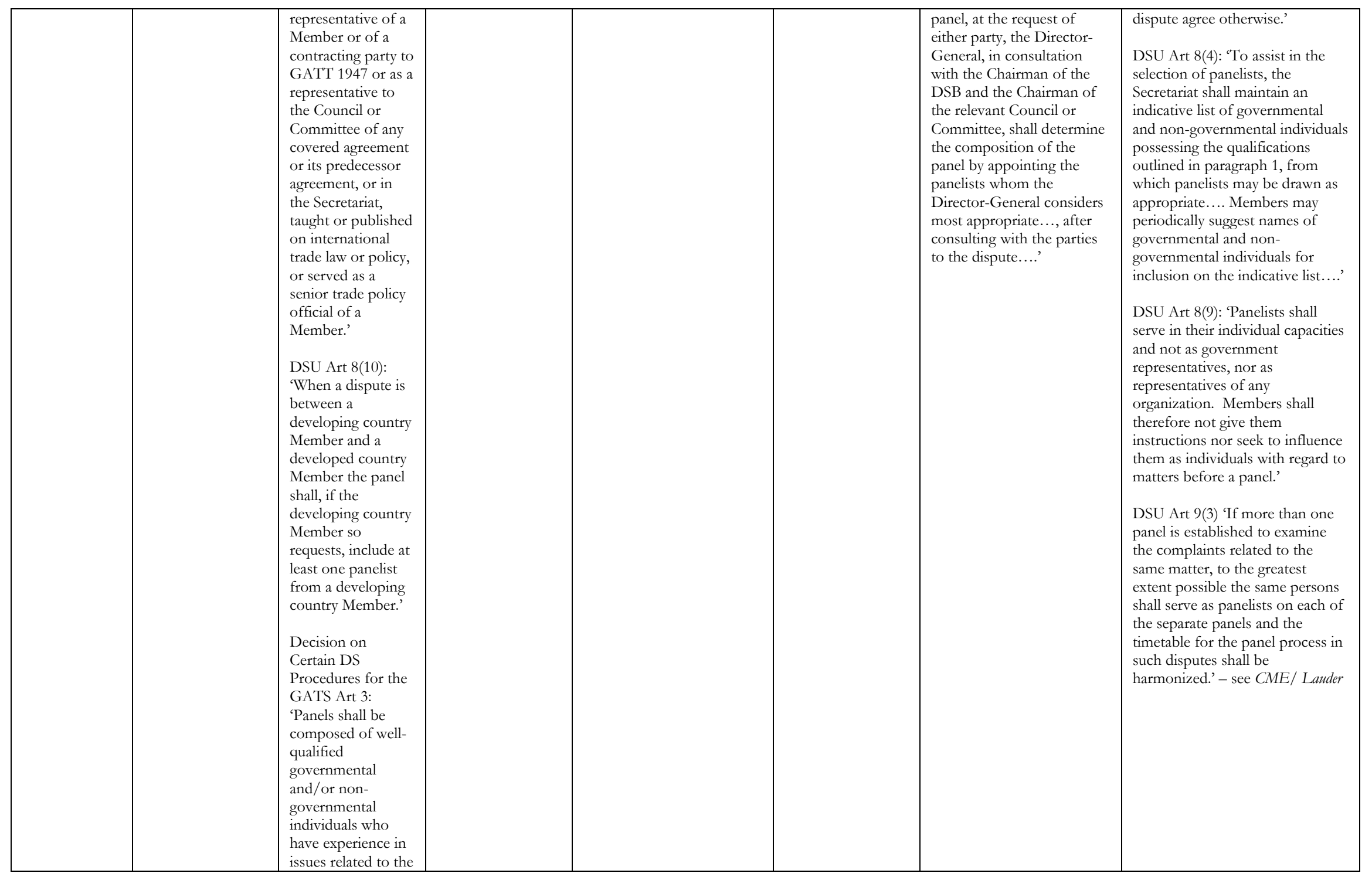




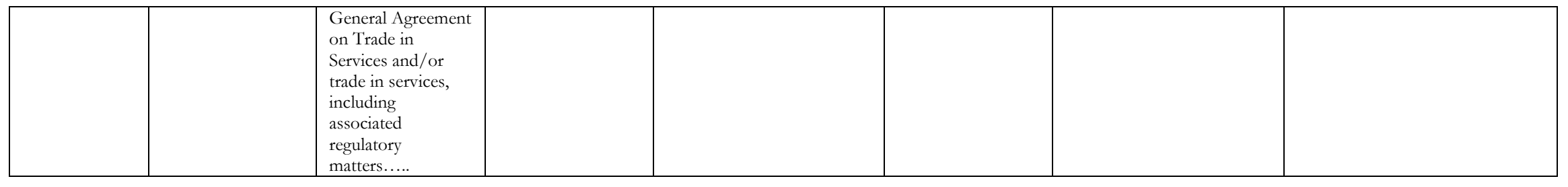

